\title{
19 Catalysis and organometallic chemistry of monometallic species
}

\author{
Richard E. Douthwaite* \\ Department of Chemistry, University of York, Heslington, York, UK YO10 5DD
}

Highlights of 2002 include the first metal complexes of stable aryl phosphino carbenes 1, that may herald a new class of ligand for homogeneous catalysis; ${ }^{1}$ the structure of the $\left\{\mathrm{Cp}_{2}{ }_{2} \mathrm{Ti}^{+}\right.$cation 2 that exhibits two agostic $\mathrm{C}-\mathrm{H}$ interactions from adjacent methyl groups on the same ring, ${ }^{2}$ the first examples of three coordinate iron(II)methyl and cobalt(II)methyl complexes, ${ }^{3}$ and detection of the elusive rhodium(I) hydride $\left[\mathrm{HRh}(\mathrm{CO})_{4}\right]^{4}$

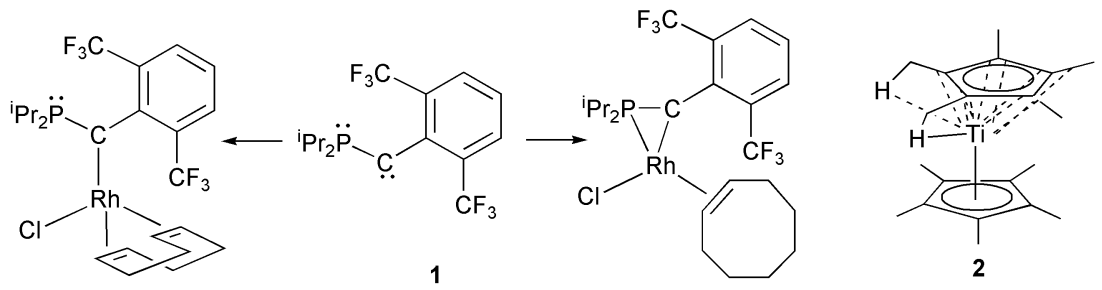

\section{Introduction}

Reviews and articles on individual classes of ligands that encompass metals across several groups include those on $\mathrm{N}$-heterocyclic carbenes ${ }^{5,6}$ and related triazolium ${ }^{7}$ and anionic borane $\mathrm{N}$-heterocyclic carbene derivatives, ${ }^{8} \beta$-diketiminato metal complexes, ${ }^{9} \mathrm{NO}^{10}$ and organonitroso complexes, ${ }^{11}$ high oxidation state multiple metal-carbon bonds, ${ }^{12}$ and the synthesis and catalytic application of metal carbonyl cations. ${ }^{13}$ A personal perspective of a half-century of nonclassical organometallic chemistry ${ }^{14}$ has also been published.

Metallocene chemistry was again prominent in 2002. Reviews on the nature of the indenyl effect ${ }^{15}$ and the evolution and nature of ansa-bridge metallocenes ${ }^{16}$ have been published. The spatial distribution of valence electrons in metallocenes studied by Penning ionisation electron spectroscopy ${ }^{17}$ and the synthesis of ansa-bridged metallocenes by metathesis ${ }^{18}$ have also been reported. Synthesis and dynamic behaviour of molecular propellers of the type $\left(\mathrm{C}_{n} \mathrm{R}_{n}\right) \mathrm{ML}_{x}$ e.g. the molecular gear $\mathbf{3}$ (where $\mathrm{R}=$ alkyl 
or aryl, $n=5,6$, or 7 , and $\mathrm{ML}_{x}$ is an organometallic fragment) have been reviewed. ${ }^{19}$ Novel cyclynes such as $\mathbf{4}$ have also been synthesised exhibiting new metallocenederived topologies. ${ }^{20}$ New tetra- and pentacyclopropenylenecyclopentadienyl metallocenes have been prepared ${ }^{21}$ and a general method reported for the synthesis of $\pi$ complexes of a diverse range of 1,2-azaborolyls. ${ }^{22}$ The synthesis, structure, and redox properties of mixed-sandwich first row transition metal complexes of $\mathrm{Cp}, \mathrm{Cp}$ * and $\mathrm{Tp}$ has also been reported. ${ }^{23}$
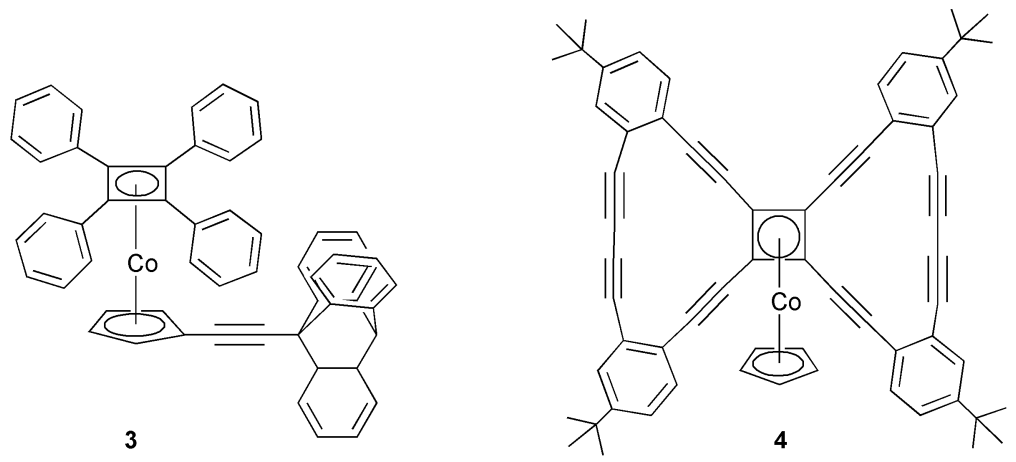

A brief history and prospects of $\mathrm{C}-\mathrm{H}$ bond activation ${ }^{24}$ and a theoretical investigation of methane activation by first row transition metals have been published. ${ }^{25}$ Reactions and mechanistic aspects of late transition metal catalysed $\mathrm{C}-\mathrm{C}$ bond formation involving $\mathrm{C}-\mathrm{H}$ activation ${ }^{26}$ and the addition of aromatic ortho $\mathrm{C}-\mathrm{H}$ bonds to olefins and acetylenes have also been reviewed. ${ }^{27}$

The synthesis and reactivity of early transition metal hydrides ${ }^{28}$ has been reviewed and the hydride donor abilities of some metal diphosphine ${ }^{29}$ and formyl ${ }^{30}$ complexes studied.

A selection of reviews of catalytic reactions or processes where organometallic species are prominent include an historical perspective of 30 years of the crosscoupling reaction, ${ }^{31}$ metal-mediated hydrodehalogenation of organic halides, ${ }^{32}$ silicon-based cross coupling reactions, ${ }^{33}$ halide effects in transition metal-mediated catalysis, ${ }^{34}$ aryl-aryl bond formation, ${ }^{35}$ development of $\mathrm{C}-\mathrm{C}$ bond formations catalysed by late transition metals in air and water, ${ }^{36,37}$ enantiomerically pure planar chiral organometallic complexes via facially selective $\pi$-complexation, ${ }^{38}$ and inventing reactions for atom economy. ${ }^{39}$ Organometallic catalysis performed in ionic liquids, ${ }^{40}$ under the action of a microwave field,,$^{41}$ on dendrimer ${ }^{42}$ and solid supports ${ }^{43}$ have also been reviewed.

Reviews have been published of cationic transition metal-mediated stereo-selective alkene polymerisation reactions, ${ }^{44}$ and aqueous catalytic polymerisation using transition metal complexes. ${ }^{45}$ Computational insights into the polymerisation of polar alkene monomers have also been investigated, ${ }^{46}$ as has the production of low molecular weight oxygenates from ethene and carbon monoxide. ${ }^{47}$ The behaviour of $1, n$-eynes in the presence of transition metals, ${ }^{48}$ transition metal complexes of 1,3 - 
diynes, poly-ynes and related compounds, ${ }^{49}$ and metal catalysed [3 +2$]$ cycloadditions have also been reviewed. ${ }^{50}$

Time resolved spectroscopic techniques have been used to probe the mechanism and dynamics of photochemical reactions including bond dissociation, isomerisation, and inter-ligand electron transfer. ${ }^{51}$ Time resolved spectroscopy applied to the migratory insertion reaction has also been reviewed. ${ }^{52}$ Known and new gas phase metal cyanide complexes have been generated by laser ablation and examined by mass spectrometry and proposed structures supported by DFT calculations. ${ }^{53}$

\section{Titanium, zirconium, hafnium}

In 2002 Group 4 organometallic chemistry was again dominated by the synthesis and study of metallocenes and their derivatives, and in particular application to alkene oligomerisation and polymerisation. The electronic influence of ring substituents and ansa-bridges in zirconocene complexes has been investigated by IR spectroscopy and supported by DFT calculations. ${ }^{54}$ The syntheses of new titanium, zirconium, and hafnium(IV) ansa-bridged metallocenes containing a $\mathrm{GeMe}_{2}$ bridge, ${ }^{55} \mathrm{SiMe}_{2}$ bridged unsymmetrical ansa-zirconocene complexes, ${ }^{56}$ and ansa-titanocene that contain bridging $\mathrm{C}_{5}$ and $\mathrm{C}_{8}$ long aliphatic chains ${ }^{57}$ have been reported. New indenyl-fluorenyl ansa-zirconocenes such as $\mathbf{5}$ have been used to regioselectively introduce allyl alcohol into non-polar polyolefins. ${ }^{58}$ The chemistry of hybrid -Cp ligands in constrained geometry complexes have also been investigated. Examples include titanium and zirconium(IV) $\mathrm{Cp}$-phosphido, ${ }^{59} \mathrm{Cp}$-imido, ${ }^{60}$ and chiral-at-metal titanium and zirconium(IV) Cp-amido complexes. ${ }^{61,62}$

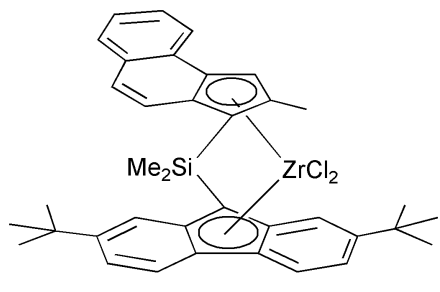

5

Phenoxy-imine and related Schiff base ligands systems have been investigated for titanium and zirconium(IV)-mediated alkene polymerisation reactions, ${ }^{63}$ particularly fluorinated derivatives, ${ }^{64-67}$ and a potential radical deactivation mechanism of this class of polymerisation catalyst identified. ${ }^{68}$ Other group 4 systems studied for alkene polymerisation include titanium(Iv) iminoimidazolidides, ${ }^{69}$ such as 6 , hafnium(IV) pyrrolide-imines, ${ }^{70,71}$ cyclopenta[b]pyridine, ${ }^{72}$ and triphosphorus macrocycles. ${ }^{73}$ The stability of zirconium(IV) $\mathrm{Cp}$ acetamidinates bearing alkyl substituents ${ }^{74}$ and the direct observation of structural isomerisation of an insertion product has been investigated by NMR spectroscopy. ${ }^{75} \mathrm{~A}$ kinetic study of $\beta$-methyl elimination in $\left[\mathrm{Hf}\left(\eta^{5}-\mathrm{C}_{5} \mathrm{Me}_{5}\right)_{2}\left(\mu-\mathrm{MeB}\left(\mathrm{C}_{6} \mathrm{~F}_{5}\right)_{2}\right) \mathrm{R}\right]\left(\text { where } \mathrm{R}=\mathrm{Me} \text { and } \mathrm{CH}_{2} \mathrm{CMe}_{3}\right)^{76}$ and $\mathrm{C}-\mathrm{H}$ activation of the aromatic substituents of $\mathrm{Cp}$ ligands coordinated to a $\left\{\mathrm{Ti}\left(\mathrm{CH}_{2} \mathrm{Ph}\right)_{3}\right\}$ 
moiety, ${ }^{77}$ and competitive metathesis and $\mathrm{C}-\mathrm{H}$ activation from reaction between $\mathrm{AlMe}_{3}$ and $\left[\mathrm{TiMe}_{2}\left(\mathrm{NP}^{t} \mathrm{Bu}_{3}\right)_{2}\right]$ have been reported. ${ }^{78}$

Intermolecular $\mathrm{C}-\mathrm{H}$ and $\mathrm{C}-\mathrm{F}$ activation by group 4 complexes include computational evidence for the role of alkane adducts in selective $\mathrm{C}-\mathrm{H}$ activation by titanium amido complexes ${ }^{79}$ and activation of arene $\mathrm{C}-\mathrm{H}$ bonds by cationic hafnium(IV) silyl complexes. ${ }^{80}$ The mechanism of $\mathrm{C}-\mathrm{F}$ activation of nonperfluorinated alkenes ${ }^{81}$ and arenes ${ }^{82}$ using $\left[\mathrm{Zr}\left(\eta^{5}-\mathrm{C}_{5} \mathrm{Me}_{5}\right)_{2} \mathrm{H}_{2}\right]$ and the synthesis of the tetrafluorobenzyne derived complex $\left[\mathrm{Zr}\left(\eta^{5}-\mathrm{C}_{5} \mathrm{Me}_{5}\right)\left(\eta^{5}-\mathrm{C}_{5} \mathrm{Me}_{4} \mathrm{CH}_{2} \mathrm{C}_{6} \mathrm{~F}_{4}\right) \mathrm{F}\right]$ from reaction between $\left[\mathrm{Zr}\left(\eta^{5}-\mathrm{C}_{5} \mathrm{Me}_{5}\right)_{2} \mathrm{H}_{2}\right]$ and $\mathrm{C}_{6} \mathrm{~F}_{6}$ have also been described. ${ }^{83}$

New ligand systems applied to group 4 include complexes of $3 \mathrm{a}, 7 \mathrm{a},-$-azaborindenyl, 7 an isoelectronic analogue of indenyl, ${ }^{84}$ and a zirconium (IV) complex of a partially hydrogenated corranulene ('buckybowl'). ${ }^{85}$ The first structurally characterised homoleptic $\sigma$-organotitanium(III) complex $\left[\mathrm{Ti}\left(\mathrm{C}_{6} \mathrm{Cl}_{5}\right)_{4}\right]^{-}$is mononuclear with $T_{\mathrm{d}}$ symmetry. ${ }^{86}$ The structure of the decamethytitanocene complex, $2\left[\mathrm{Cp}^{*}{ }_{2} \mathrm{Ti}^{\mathrm{III}}\right]\left[\mathrm{BPh}_{4}\right]$ shows two agostic $\mathrm{C}-\mathrm{H}$ bonds and the reactivity of this complex in the presence of fluorocarbons is reported. ${ }^{2}$ The $\mathrm{Cp}^{*}$ ring that does not participate in agostic bonding is $\eta^{5}$ whilst the other is slipped back resulting in two shorter Ti- $\mathrm{C}_{\mathrm{Cp}^{*}}$ distances of the carbons that are attached to the agostic methyl groups. In agreement with theoretical work a bent metallocene geometry is adopted. On addition of fluorobenezene an $\eta^{1}-\mathrm{FC}_{6} \mathrm{H}_{5}$ adduct is formed that no longer exhibits agostic bonding. Comparison between zirconium(IV) dicarbonyl complexes of $\mathrm{Cp}^{*}$ and the phosphacyclopentadienyl $\mathrm{C}_{5} \mathrm{Me}_{4} \mathrm{P}$ showed that $\mathrm{C}_{5} \mathrm{Me}_{4} \mathrm{P}$ should be considered a poorer $\pi$-base that $\mathrm{Cp}^{*}{ }^{87}$

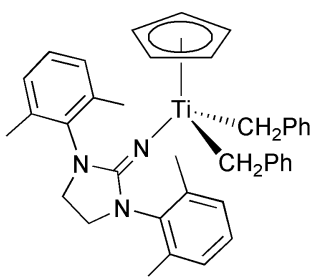

6

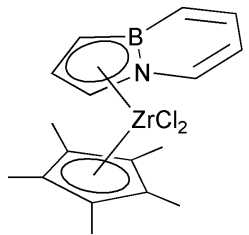

7

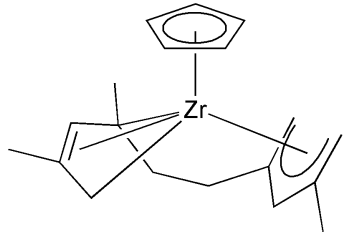

8

Other metal-based transformations of organic ligands include the unusual reactivity exhibited by 2 equivalents of the metal-based titanium(III) radical $\left[\mathrm{Ti}\left(\mathrm{N}^{\mathrm{t}} \mathrm{Bu}-\right.\right.$ $\left.\left.\left(3,5-\mathrm{Me}_{2} \mathrm{C}_{6} \mathrm{H}_{4}\right)\right)_{3}\right]$ that cleaves the $\mathrm{C}-\mathrm{C}$ bond of symmetrical 1,4-diketones to give the corresponding titanium enolates. ${ }^{88}$ Half-open zirconocenes prepared from reaction between $\left[\mathrm{ZrBrCl}_{2}\left(\eta^{5}-\mathrm{C}_{5} \mathrm{H}_{5}\right)\right]$ and dimethylpentadienyl $\mathrm{K}\left[2,4-\mathrm{C}_{7} \mathrm{H}_{11}\right]$ gives $\left[\mathrm{Zr}\left(\eta^{5}-\mathrm{C}_{5} \mathrm{H}_{5}\right) \mathrm{C}_{14} \mathrm{H}_{21}\right] \mathbf{8}$ that based on X-ray crystallography is possibly best described as a zirconium(IV) enediyl complex, ${ }^{89}$ and the formation of 1,2,3,5-tetrasubstituted benzenes via formal $\mathrm{C}-\mathrm{C}$ double bond cleavage of zirconacyclopentadienyls has been described. ${ }^{90}$

Finally an application of diffusion-ordered NMR spectroscopy (DOSY) has been reported for reaction between ${ }^{13} \mathrm{CO}_{2}$ and $\left[\mathrm{Zr}\left(\eta^{5}-\mathrm{C}_{5} \mathrm{H}_{5}\right)_{2} \mathrm{Cl}(\mathrm{H})\right]$ demonstrating a very powerful technique for the analysis of reaction mixtures in situ. ${ }^{91}$ 


\section{Vanadium, niobium, tantalum}

The application of group 5 metal complexes to alkene polymerisation includes the synthesis and electrochemistry of niobium(v) unsymmetric ansa-bridged niobacene complexes, ${ }^{92}$ and tantalum(v) metallocene, half metallocene and non-metallocene complexes derived from hybrid $\mathrm{Cp}$-amido and di-amido ligands for the copolymerisation of ethene and 1-octene and polymerisation of methylmethacrylate. ${ }^{93}$ Vanadocene complexes containing amino functionalised $\mathrm{Cp}$ ligands have also been investigated for the polymerisation of butadiene. ${ }^{94}$ Also of relevance to cationic metal-mediated polymerisation catalysis the complex $\left[\mathrm{V}\left(\eta^{5}-\mathrm{C}_{5} \mathrm{H}_{5}\right)_{2} \mathrm{Me}\left(\mathrm{CH}_{3} \mathrm{CN}\right)\right]\left[\mathrm{BPh}_{4}\right]$ has been structurally characterised and the reaction between $\left[\mathrm{V}\left(\eta^{5}-\mathrm{C}_{5} \mathrm{H}_{5}\right)_{2} \mathrm{Me}_{2}\right]$ and $\mathrm{B}\left(\mathrm{C}_{6} \mathrm{~F}_{5}\right)_{3}$ investigated by ESR. ${ }^{95}$ Reaction of tantalocene moieties and the coordinated boratoalkene $\mathrm{CH}_{2} \mathrm{~B}\left(\mathrm{C}_{6} \mathrm{~F}_{5}\right)_{2}$ have also been studied initially with respect to potential coordination modes demonstrating alkene-like behaviour ${ }^{96}$ and subsequently isonitrile insertion. ${ }^{97}$

Very unusual homoleptic $\eta^{4}$ - naphthalene and anthracene complex anions of niobium $(-\mathrm{I})$ and tantalum( $(-\mathrm{I})$ including $[\mathrm{K}(\mathrm{THF})]\left[\mathrm{Nb}\left(\eta^{4}-\mathrm{C}_{14} \mathrm{H}_{10}\right)_{3}\right] 9$ and $[\mathrm{Na}-$ (THF)][Ta $\left.\left(\eta^{4}-\mathrm{C}_{10} \mathrm{H}_{8}\right)_{3}\right] \mathbf{1 0}$ have been synthesised, structurally characterised and some reactivity investigated. It is suggested that these complexes could be used as convenient starting materials for entry into low valent niobium and tantalum chemistry ${ }^{98,99}$ The first structural characterisation of a metalloceneol is represented by the vanadium(II) complex $\left[\mathrm{V}\left(\eta^{5-} \mathrm{C}_{5} \mathrm{H}_{4} \mathrm{OH}\right)\left(\eta^{7}-\mathrm{C}_{7} \mathrm{H}_{7}\right)\right]^{100}$ and a theoretical study into Jahn-Teller effects in singlet and low energy triplet states of $\left[\mathrm{Nb}\left(\eta-\mathrm{C}_{6} \mathrm{H}_{6}\right)(\mathrm{CO})_{3}\right]^{+}$and $\left[\mathrm{Nb}\left(\eta^{5}-\mathrm{C}_{5} \mathrm{H}_{5}\right)(\mathrm{CO})_{3}\right]$ indicates that Jahn-Teller effects are operative in both singlet and low-energy triplet states for unsaturated $\left\{\mathrm{CpML}_{3}\right\}$ complexes. ${ }^{101}$

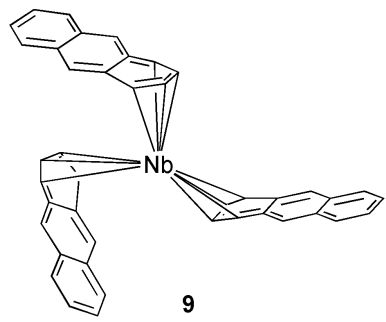

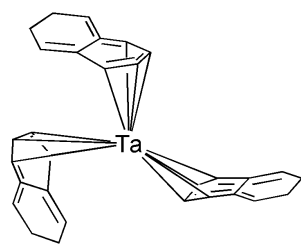

10

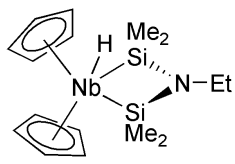

11

Silyl derivatives of group 5 organometallic complexes have been investigated including intramolecular $\mathrm{C}-\mathrm{H}$ activation of silyl ligands by tantalum(v) imido moieties ${ }^{102}$ and the formation of an unusual imido-bridged 1,3-disilaniocyclobutane $\mathbf{1 1}$ from reaction between $\left[\mathrm{Nb}\left(\eta^{5}-\mathrm{C}_{5} \mathrm{H}_{5}\right)(\mathrm{H})\left(\mathrm{SiMe}_{2} \mathrm{I}\right)_{2}\right]$ and $\mathrm{H}_{2} \mathrm{NEt}_{2} .{ }^{103}$

Hydrogenation of aromatics ${ }^{104}$ and intramolecular hydride transfers to aromatic rings have been studied and an investigation into dihydrogen addition to $\left[\mathrm{Ta}\left(\mathrm{CH}_{2}\right)\right.$ $\left.\left(\eta^{5}-\mathrm{C}_{5} \mathrm{Me}_{5}\right)_{2}(\mathrm{H})\right]$ using parahydrogen has also been reported. ${ }^{105}$

Insertion processes of a series of niobium(v) alkyl and alkyne complexes have been investigated and supported by DFT calculations ${ }^{106}$ and the coupling of 1-aza-1,3butadiene and iminoacyl ligands to give amido-imido complexes of tantalum(v) reported. ${ }^{107}$ The synthesis of organotantalum reagents and conjugate additions to enones has also been reviewed. ${ }^{108}$ 
An unusual reaction reported between $\mathrm{Nb}^{+}$and $\mathrm{C}_{6} \mathrm{~F}_{6}$ in the gas phase gives multiple $\mathrm{C}-\mathrm{F}$ bond cleavage leading to the formation of difluorohexatriyne and $\left[\mathrm{NbF}_{4}\right]^{+}$that was analysed by mass spectrometry techniques. ${ }^{109}$

\section{Chromium, molybdenum, tungsten}

Two articles charting the discovery and study of bis(benzene)chromium give an interesting account of this prototypical transition metal arene complex. ${ }^{110,111}$ Theoretical and NMR evidence indicate that the effective aromaticity of $\left[\mathrm{Cr}\left(\eta^{6}\right.\right.$-arene $\left.)(\mathrm{CO})_{3}\right]$ is $25 \%$ greater than that of benzene itself. ${ }^{112}$ Metalated $\left[(\eta\right.$-arene $\left.) \operatorname{Cr}(\mathrm{CO})_{3}\right]$ complexes in organometallic chemistry have been reviewed ${ }^{113}$ and an interesting example of a nonclassical hydrogen bond found in $\left[\mathrm{Mo}\left(\eta^{6}-\mathrm{C}_{6} \mathrm{H}_{5} \mathrm{C}_{6} \mathrm{H}_{3}(\mathrm{Ph}) \mathrm{OH}\right)\left(\mathrm{PMe}_{3}\right)_{3}\right], 12$. DFT calculations indicate that this facilitates intramolecular oxidative addition of the $\mathrm{O}-\mathrm{H}$ bond. ${ }^{114}$ Structural and spectroscopic studies have been used to investigate the bonding of alkynes to chromium arene complexes as a function of chromium oxidation state. $^{115}$ A new series of homoleptic $\sigma$-bonded arene chromium complexes $[\mathrm{Cr}$ $\left.\left(\mathrm{C}_{6} \mathrm{Cl}_{5}\right)_{4}\right]^{n-}(n=0-2)$ have been prepared that show interesting structural features. For $n=2$ the chromium(II) ion exhibits a square planar geometry whereas for $n=1$ the chromium(III) ion is pseudooctahedral due to two additional $\mathrm{Cr}-\mathrm{Cl}$ interactions. ${ }^{116}$

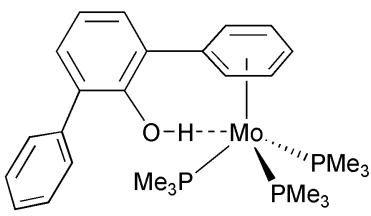

12

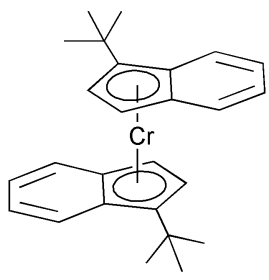

13

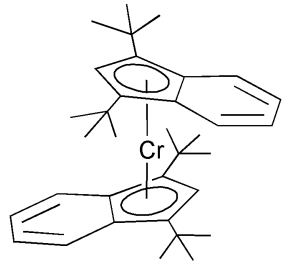

14

The bis(indenyl) chromium(II) complex 13 has a high spin state whereas 14 exhibits a low spin state due to restricted rotation of the indenyl rings allowing the possibility of using restricted rotation as a means of spin state manipulation in these systems. ${ }^{117}$ The structural effect due to Jahn-Teller distortion in the high spin chromium(II) complex $\left[\mathrm{Cr}\left(\eta^{5}-\mathrm{C}_{5} \mathrm{Me}_{5}\right)(\mathrm{Tp})\right]$ has also been studied. ${ }^{118}$

DFT, NMR spectroscopy, and X-ray crystallography have been used to investigate the bonding in the unusual trigonal prismatic structure of tris(cis-1,3-butadiene)molybdenum 15 and related complexes with the conclusion that metallocyclopentene

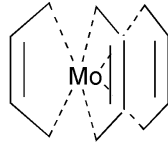

15

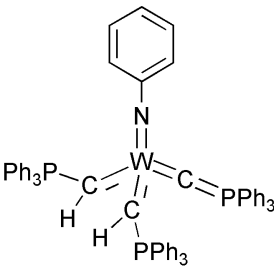

16 
resonance structures rather than $\pi$-bonded di-olefins offer a more accurate representation of the bonding. ${ }^{119}$ A neutron diffraction study of a tungsten methylidyne complex has confirmed the linearity of the $\mathrm{M}-\mathrm{C}-\mathrm{H}$ vector. ${ }^{120}$

In the field of $\mathrm{C}-\mathrm{H}$ activation theoretical studies of the spin crossover transition states for the addition of methane to a series of group 6 metallocenes including ansaderivatives, ${ }^{121}$ and $\mathrm{C}-\mathrm{H}$ activation in $\left[\mathrm{W}\left(\eta^{5}-\mathrm{C}_{5} \mathrm{H}_{5}\right) \mathrm{Me}{ }_{2} \mathrm{NO}\right]$ and $\left[\mathrm{W}\left(\eta^{5}-\mathrm{C}_{5} \mathrm{H}_{5}\right)-\right.$ $\left.(\mathrm{CO}) \mathrm{Me}_{2}\right]^{-}$complexes $^{122}$ have been published. Intermolecular $\mathrm{C}-\mathrm{H}$ activations mediated by tungsten alkylidene, ${ }^{123}$ tungsten allene ${ }^{124}$ and tungsten aryl complexes have also been reported. ${ }^{125}$

$\mathrm{C}-\mathrm{X}$ bond cleavage where $\mathrm{X}=\mathrm{O}, \mathrm{Si}$ and $\mathrm{S}$ have all been investigated, as have carbonyl extraction from $\mathrm{CO}_{2},\left(\mathrm{CH}_{2} \mathrm{O}\right)_{n}, \mathrm{HCO}_{2} \mathrm{H}$, and $\mathrm{MeOH}$ and the catalytic decarboxylation of formic acid using $\left[\mathrm{Mo}\left(\eta^{5}-\mathrm{C}_{5} \mathrm{Me}_{5}\right)\left(\mathrm{PMe}_{3}\right)_{3} \mathrm{H}\right],{ }^{126}$ cleavage of $\mathrm{Si}-\mathrm{Ar}$ and $\mathrm{Si}-\mathrm{Me}$ bonds that are dependent on the countercation of substituted arene $\mathrm{CrCO}_{3}$ anion complexes, ${ }^{127}$ and chromium(II) radical initiated $\mathrm{C}-\mathrm{S}$ cleavage in dithiocarbamate and thiocarbenoind complexes. ${ }^{128}$ Molybdenum nitrogen and sulfur heterocycle complexes relevant to hydrodenitrogenation ${ }^{129}$ and hydrodesufurisation ${ }^{130}$ respectively have also been prepared and structurally characterised.

Several examples of new alkyne and alkanyl complexes and their chemistry have been investigated including a structurally characterised $N, N^{\prime}, N^{\prime \prime}$-trimethyl1,4,7-triazacyclononane chromium(II) triacetylide complex that binds alkali metal cations, ${ }^{131}$ insertion of 3 -hexyne into a molybdenum amido bond, ${ }^{132}$ molybdenum(II) complexes as acetylide transfer agents, ${ }^{133,134}$ and molybdenum-mediated cyclotrimerisation of alkyne and phosphaalkynes. ${ }^{135}$ The first example of a terminal phosphinomethylidene complex 16 has also been reported. ${ }^{136}$

Metallocene chemistry includes the ansa-bridge complex $\left[\mathrm{Cr}\left(\mathrm{C}_{2} \mathrm{Me}_{4}\left(\eta^{5}-\mathrm{C}_{5} \mathrm{H}_{4}\right)\right)_{2} \mathrm{CO}\right]$ that can be protonated to give a transient chromium(IV) hydride, ${ }^{137}$ zwitterionic ringborylated ansa-chromacene complexes, ${ }^{138}$ formerly elusive 17 -electron half sandwich chromium(II/III) complexes ${ }^{139}$ and molybdenum and tungsten-mediated catalytic ionic hydrogenation of ketones. ${ }^{140}$ Examples of chiral molybdenum cycloheptatrienylphenolates have also been prepared. ${ }^{141}$

\section{Manganese, technetium, rhenium}

Reviews of the medicinal uses of organometallic technetium compounds for radiopharmaceuticals and particularly for the receptor function of the central nervous system have been published. ${ }^{142-144}$

The study and reactivity of alkyl rhenium oxides including the structure and vibrational properties of $\left[\mathrm{ReEtO}_{3}\right]$ have been investigated by electron diffraction, X-ray crystallography, IR spectroscopy and DFT calculations. ${ }^{145}$ The matrix photochemistry of $\left[\mathrm{ReMe}_{3} \mathrm{O}_{2}\right]$, ${ }^{146}$ and $\left[\mathrm{ReMe}_{4} \mathrm{O}\right]{ }^{147}$ has shown evidence for rhenium methylidene species relevant to the use of this class of complex as metathesis catalysts. Reactivity studies of methyl rhenium(v) oxo complexes that catalyse the sulfoxidation of thioethers to sulfoxides have also been isolated. ${ }^{148}$ In a further study an usual methyl migration shown in Scheme 1 from Re to a coordinated thiolate sulfur ligand mimicking the conversion of $\mathrm{D}, \mathrm{L}$-homocysteine to L-methionine in vitamin $\mathrm{B}_{12}$ has 


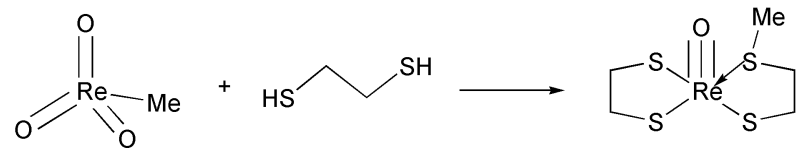

Scheme 1

been observed. ${ }^{149}$ The synthesis and reactivity of methyl complexes of five coordinate rhenium(VII) dioxo and diimido complexes have also been reported. ${ }^{150}$

Alkene complexes of group 7 metals have also been of interest. Manganese(I) and rhenium(I) hydride, vinylidene and allenylidene complexes of a triphosphorus macrocycle have been isolated. ${ }^{151}$ The stereoselective alkene binding to chiral $\left[\operatorname{Re}\left(\eta^{5}-\mathrm{C}_{5} \mathrm{H}_{5}\right)(\mathrm{NO})\left(\mathrm{PPh}_{3}\right)\right]^{+}$of a number of 1-enes have been studied using molecular mechanics, semiempirical quantum mechanics and DFT, with the aim of aiding ligand design. ${ }^{152}$ DFT calculations have been used to investigate the acetylene to vinylidene isomerisation in $\left[\mathrm{Mn}\left(\eta^{5}-\mathrm{C}_{5} \mathrm{H}_{5}\right)(\mathrm{CO})_{2}(\mathrm{HCCH})\right] \cdot{ }^{153} \mathrm{~A}$ redetermination of the single crystal X-ray structure of [Mn(bis(cis-1,3-butadiene) $) \mathrm{CO}$ ] supported by DFT calculations to determine accurate $\mathrm{C}-\mathrm{C}$ bond lengths in the butadiene moiety has been reported. ${ }^{154} \mathrm{~A}$ similar conclusion to that of a related study ${ }^{119}$ showed that the original interpretation of the X-ray data gave too disparate internal and terminal $\mathrm{C}-\mathrm{C}$ bonds lengths. Photon electron spectroscopy and DFT calculations have been used to compare the electronic structures of alkyl and hydride complexes of the moiety $\left\{\operatorname{Re}\left(\eta^{5}-\mathrm{C}_{5} \mathrm{H}_{5}\right)(\mathrm{NO})(\mathrm{L})\right\}$ that show that the methyl group may be acting as a weak $\pi$-donor ${ }^{155}$ and a detailed FTIR and Raman normal coordinate analysis of $\left[\mathrm{M}\left(\eta^{5}-\mathrm{C}_{5} \mathrm{H}_{5}\right) \mathrm{L}_{3}\right](\mathrm{M}=\mathrm{Mn}$ and $\mathrm{Re}, \mathrm{L}=\mathrm{CO}$ and $\mathrm{O})$ allows estimation of the force constant for the M-Cp ligand bond stretch in half sandwich complexes. ${ }^{156}$

Time resolved IR and flash photolysis have been used to investigate reactive intermediates relevant to the carbonylation of $\mathrm{MeMn}(\mathrm{CO})_{5}$ and determine activation parameters. ${ }^{157}$ Relevant to Fischer-Tropsch an unusual reaction between $\left[\mathrm{Mn}(\mathrm{CO})_{5^{-}}\right.$ $\left.\left(\mathrm{Si}(p-\mathrm{Tol})_{2} \mathrm{H}\right)\right](\mathrm{Tol}=$ tolyl $)$ and hydride transfer agents leads to reduction of the carbonyl ligands followed by $\mathrm{Si}-\mathrm{C}$ and $\mathrm{C}-\mathrm{C}$ bond formation to give $\mathrm{MeSi}(p-\mathrm{Tol})_{2} \mathrm{OH}$ and $\operatorname{EtSi}(p-\mathrm{Tol})_{2} \mathrm{OH} .^{158}$

Addition of $\mathrm{N}-\mathrm{H}$ and $\mathrm{S}-\mathrm{H}$ bonds across rhenium allenylidene complexes ${ }^{159}$ and the structural isomers of rhenium aryl substituted $\eta^{3}$-propargyl complexes have been thoroughly studied. ${ }^{160}$ The reactivity of " $\left[\mathrm{Mn}\left(\mathrm{CH}_{2}{ }^{\mathrm{t}} \mathrm{Bu}\right)_{2}\right]$ " on coordination of diimine ligands has been investigated with reference to alkene polymerisation chemistry and has shown that $\mathrm{C}-\mathrm{C}$ activation of the ligand can occur. ${ }^{161}$

An $\mathrm{N}$-confused porphyrin complex of manganese $\mathbf{1 7}$ has been prepared from $\mathrm{C}-\mathrm{H}$

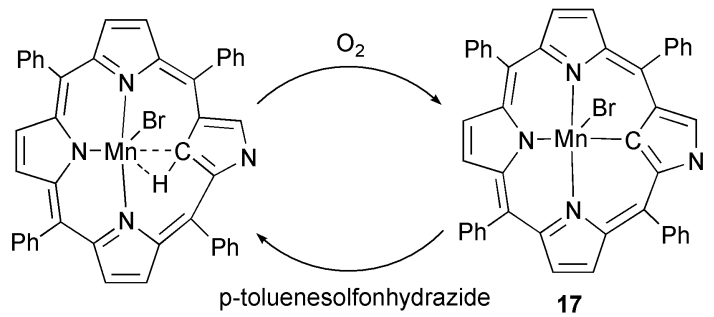


activation under the action of dioxygen, ${ }^{162}$ and the oxidation of hydrocarbons by $\left[\mathrm{MnCF}_{3} \mathrm{C}(\mathrm{O}) \mathrm{CHC}(\mathrm{O}) \mathrm{CF}_{3}\right]$ has been demonstrated. ${ }^{163}$

The single crystal-single crystal solid state transformation of cis-trans isomers of $\left[\mathrm{Re}\left(\eta^{5}-\mathrm{C}_{5} \mathrm{H}_{4} \mathrm{Me}\right)(\mathrm{CO})\left(\mathrm{P}(\mathrm{OPh})_{3}\right) \mathrm{Br}_{2}\right]$ has been studied by single crystal X-ray diffraction at $150{ }^{\circ} \mathrm{C}$. The isomerisation follows first order kinetics and a rate constant of $30 \times 10^{-6} \mathrm{~s}^{-1}$ is obtained. The mechanism entails a unidirectional anticlockwise movement of the $\mathrm{CO}$ ligand and only one $\mathrm{Br}$ atom, which differs from the proposed isomerisation in solution. ${ }^{164}$

\section{Iron, ruthenium, osmium}

Reviews on ruthenium and osmium porphyrin carbene complexes and their connection to metal-mediated cyclopropanation of alkenes ${ }^{165}$ and ground and excited state reactivities of cationic sandwich and half-sandwich complexes of iron(II) have been published. ${ }^{166}$

Developments in metathesis reactions have occurred with the synthesis of new active ruthenium(II) catalysts. A N-heterocyclic carbene ligand containing a binaphthyl substituent induces excellent enantioselectivity for some ring-opening/cross metathesis reactions in air, ${ }^{167}$ and a functionalised alkylidene incorporating a hemilabile ether moiety has been investigated for ring closing metathesis. ${ }^{168}$ A DFT study on the mechanism of olefin metathesis using ruthenium(II) N-heterocyclic carbene complexes has also been investigated. ${ }^{169}$ In related chemistry a very rare example of a terminal carbide ligand has been isolated originating from a unique carbon atom transfer reaction as shown in Scheme 2. ${ }^{170}$ The copolymerisation of ethene and polar monomers has been investigated using iron(II) bisiminopyridine complexes. Copolymerisation studies of ethene and polar monomers such as methylmethacrylate, vinyl acetate and vinyl chloride have been reported ${ }^{171}$ and a detailed investigation by NMR spectroscopy outlines the elimination processes that terminate chain growth. ${ }^{172}$

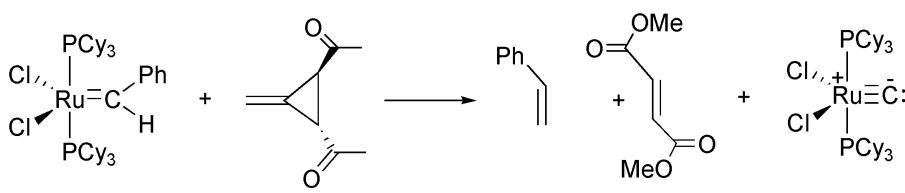

Scheme 2

Unusual intramolecular $\mathrm{C}-\mathrm{H}$ activation studies have been prevalent for a number of ligand systems including a ruthenium(II) N-heterocyclic carbene (that also exhibits C-C cleavage). ${ }^{173}$ Double $\mathrm{C}-\mathrm{H}$ activation of bis(di-tert-butylphosphino)pentane to give a ruthenium alkene 18 and an osmium carbene $19,{ }^{174}$ a triple $\mathrm{C}-\mathrm{H}$ activation reaction to give complex $\mathbf{2 0},{ }^{175}$ and reactions of $\mathrm{RuCp}$ and $\mathrm{RuCp}{ }^{*}$ alkyl complexes that exhibit a range of intramolecular $\mathrm{C}-\mathrm{H}$ activation events are also described. ${ }^{176}$ Intermolecular $\mathrm{C}-\mathrm{F}$ activation of vinyl fluoride by Os(IV) complexes has also been studied. ${ }^{177}$ 


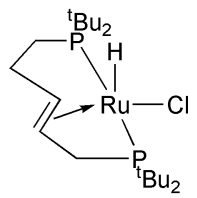

18

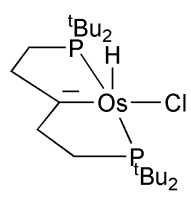

19

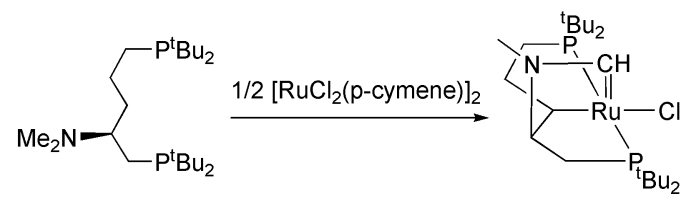

20

A range of studies examining the fluxionality and isomerisation of hydrocarbyl ligands have been reported including ruthenium(II) dihydride complexes using parahydrogen, ${ }^{178}$ alkyl isomerisation in very unusual three coordinate iron(II) complexes, ${ }^{179}$ hydride-carbyne to carbene in a CpOs complex that does not proceed via single $\alpha$-hydride migration, ${ }^{180,181}$ osmium(II) alkyne ligands as 2 and 4-electron donors, ${ }^{182}$ and metal migration in cycloheptatrienyl complexes. ${ }^{183}$ Exchange processes in $\eta^{2}$-silane complexes of ruthenium(II) have also been investigated ${ }^{184}$ and include the structure and bonding of $\left[\mathrm{CpRu}\left(\eta^{2}-\mathrm{HSiCl}_{3}\right)\left(\mathrm{PMe}_{3}\right)_{2}\right]^{+} .{ }^{185}$

Interesting developments in catalysis include the iron-catalysed cross-coupling of alkyl Grignards and aryl chlorides, tosylates and triflates. ${ }^{186}$ For the substrates examined the reaction times were very short and catalysis performed under ligand free conditions. Unusual ruthenium-catalysed oxidative Heck reactions have also have also been studied. ${ }^{187}$ New classes of catalyst include a ruthenium(II) bis(N-heterocyclic carbene)pyridine for the hydrogenation of carbonyl compounds, ${ }^{188}$ chiral ester functionalised Cp complexes of iron(II), ${ }^{189}$ and new ferrocenyl ligands exhibiting excellent enantioselectivities for asymmetric hydrogenation of amino acid synthesis. ${ }^{190}$

A linkage isomer of decaphenyl ferrocene has been isolated and structurally characterised and contains $\eta^{5}-\mathrm{C}_{5} \mathrm{Ph}_{5}$ cyclopentadienyl and $\eta^{5 / 6}-\mathrm{C}_{5} \mathrm{Ph}_{5}$ arene coordination. ${ }^{191}$ Based on structural data the bonding of the arene coordinated ligand appears to lie somewhere between an $\eta^{5}$ mode 21 and a zwitterionic $\eta^{6}$ mode 22. Other group 8 arene chemistry includes $\mathrm{CpFe}^{+}$induced amination of chloroarenes in water to give $\eta^{6}$-aminoarene complexes, ${ }^{192}$ the synthesis, structures and dynamic NMR spectra of $\eta^{6}-\mathrm{C}_{6} \mathrm{Et}_{6}$ complexes of ruthenium(II) and ruthenium(o), ${ }^{193}$ and alkyne coupling to give regio- and chemoselective formation of $\eta^{6}$-arene and pyridine complexes. ${ }^{194}$ The reaction between $\left[\mathrm{Fe}(\mathrm{CO})_{5}\right]$ and diaminoacetylene has lead to the characterisation and isolation of elusive alkyne and ferrabicyclobutenone complexes ${ }^{195}$ and alkylidene and vinylidene pincer complexes have been prepared from reaction between ruthenium(II) and osmium(IV) hydrides and alkynes. ${ }^{196}$ Insertion of aminoalkynes into ruthenium(II) allenylidene to give unusual cumulene complexes ${ }^{197}$ and the synthesis of iron(II) cyclynes similar to $\mathbf{4}$ has also been studied. ${ }^{20}$

A study of hydride transfer from $\left[\mathrm{M}\left(\eta^{5}-\mathrm{C}_{5} \mathrm{Me}_{5}\right)(\mathrm{CO})_{2} \mathrm{H}\right](\mathrm{M}=\mathrm{Fe}, \mathrm{Ru}, \mathrm{Os})$ to trityl cation details the metal dependent kinetics and product selectivity. ${ }^{198}$ Other

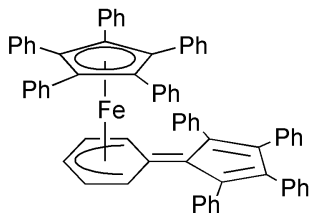

21

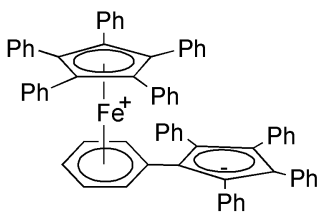

22

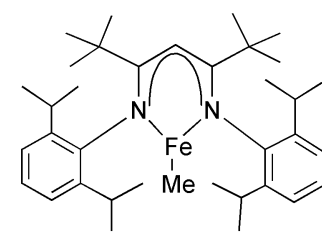

23 
metallocene chemistry includes a convenient synthetic route to the useful precursor complex $\left[\mathrm{Ru}\left(\eta^{5}-\mathrm{C}_{5} \mathrm{H}_{5}\right)(\mathrm{MeCN})_{3}\right]\left[\mathrm{PF}_{6}\right]^{199}$ and an IR study to determine the thermodynamics of cation-anion interactions in various $\left[\left(\eta^{5} \text {-pentadienyl }\right) \mathrm{Fe}(\mathrm{CO})_{2}\right]^{-}$salts. $^{200}$

The first example of a 12 electron three coordinate iron(II) methyl complex $\mathbf{2 3}$ has also been prepared and structurally characterised. The bulky $\beta$-diketiminate provides the steric protection for these low coordinate complexes. Future studies of this compound and other three coordinate derivatives may give some insight into the low coordinate metal sites present in some metalloenzymes., ${ }^{3,179}$

\section{Cobalt, rhodium, iridium}

Inter- and intramolecular $\mathrm{C}-\mathrm{H}$ and $\mathrm{C}-\mathrm{F}$ activation reactions mediated by group 9 metals were very prominent. Studies of intermolecular $\mathrm{C}-\mathrm{H}$ activation leading directly to useful products include stoichiometric and catalytic borylation of aromatic compounds at room temperature using iridium complexes, ${ }^{201,202}$ theoretical insights into the rhodium catalysed borylation of alkanes, ${ }^{203}$ the rhodium and iridium catalysed hydrogen/deuterium exchange into organic compounds in $\mathrm{D}_{2} \mathrm{O},{ }^{204,205}$ combined computational and experimental studies on PCP pincer iridium catalysed acceptorless dehydrogenation of alkanes and thermodynamics of addition of $\mathrm{H}_{2}, \mathrm{CO}$, arene and alkane to these complexes, ${ }^{206,207}$ and a rhodium catalysed $\mathrm{C}-\mathrm{H}$ activation facilitating intermolecular coupling of isomerisable alkenes with heterocycles. ${ }^{208}$

Other intermolecular activation studies include a concept article on rhodium(I) chelation-assisted $\mathrm{C}-\mathrm{H}$ and $\mathrm{C}-\mathrm{C}$ activation, ${ }^{209}$ associated investigation of $\mathrm{C}-\mathrm{H}$ activation of alkenylarenes on addition to $\mathrm{CpRh}$ complexes ${ }^{210}$ and abnormal ligand binding and reversible ring hydrogenation in the reaction of imidazolium salts with $\left[\mathrm{IrH}_{5}\left(\mathrm{PPh}_{3}\right)_{2}\right] .^{211}$ The electronic and medium effects on the rate of $\mathrm{C}-\mathrm{H}$ activation by cationic iridium(III) complexes have also been examined. ${ }^{212}$ Interesting examples of $\mathrm{C}-\mathrm{C}$ bond cleavage of organic nitriles mediated by rhodium(III) ${ }^{213}$ and iridium(III) silyl complexes ${ }^{214}$ have been discovered and an example is shown in Scheme 3.

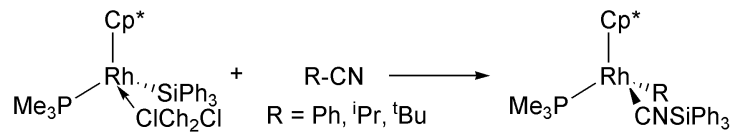

Scheme 3

Intramolecular $\mathrm{C}-\mathrm{H}$ activations include the first example with $\mathrm{N}$-heterocyclic carbenes of rhodium and iridium ${ }^{215}$ and related substituted benzimidazoles that contain an $\mathrm{N}$-heterocyclic carbene on the reaction coordinate. ${ }^{216}$ An interesting iridium(III) system with an agostic tert-butyl but a non-agostic iso-propyl group has also been reported. Theoretical calculations indicate that intra-ligand interactions compete with agostic bonding. ${ }^{217}$

Several examples of $\mathrm{C}-\mathrm{F}$ activation have been reported including dihydrogen induced conversion of an iridium(III) coordinated $\mathrm{CF}_{3}$ to $\mathrm{CO},{ }^{218}$ conversion of hexafluoropropene to 1,1,1-trifluoropropane, ${ }^{219}$ diastereoselective $\mathrm{C}-\mathrm{F}$ bond activation of iridium perflouroalkyl methyl complexes coupled with $\mathrm{C}-\mathrm{C}$ bond 
formation, ${ }^{220}$ formation of rhodium(I) and iridium(I) $\eta^{2}$-flourobenzyne complexes such as $\mathbf{2 4},{ }^{221}$ and intramolecular dehydrofluorinative coupling of $\mathrm{Cp}^{*}$ and pentafluorophenylphosphine ligands in rhodium(III) complexes. ${ }^{222}$

Complexes containing group 9 metals in unusual oxidation states include a rare example of a rhodium(II) complex $\mathbf{2 5},{ }^{223}$ an ESR study of cobalt(0), rhodium(0) and iridium( $(0)$ complexes of tropylidene phosphines ${ }^{224}$ and cobalt $(-\mathrm{I})$ in $\left[\mathrm{Co}\left(\eta^{4} \text {-anthracene }\right)_{2}\right]^{-225}$

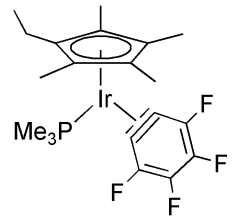

24

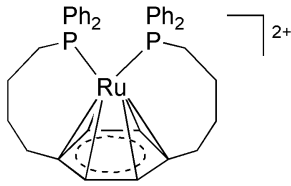

25

Several N-heterocyclic carbene complexes and their chemistry have been investigated. Chelating bis(carbene) pyridine complexes of rhodium(III) catalyse the hydrogenation of imines ${ }^{226}$ and iridium(III) complexes the transfer hydrogenation of ketones. ${ }^{227}$ Catalytic alkene hydrogenation using N-heterocyclic carbene-phosphine complexes of iridium has been studied using parahydrogen NMR spectroscopy. ${ }^{228} \mathrm{An}$ equilibrium between a tertiary phosphine and an $\mathrm{N}$-heterocyclic carbene has been observed for $\left[\mathrm{Co}\left(\eta^{5}-\mathrm{C}_{5} \mathrm{H}_{5}\right) \mathrm{Me}_{2}\left(\mathrm{PPh}_{3}\right)\right]$ and thermodynamic parameters determined. ${ }^{229}$ Related rhodium(I) and iridium(I) complexes of the non-cyclic carbene bis(diisopropylamino)carbene have been isolated for the first time. IR spectroscopy of rhodium(I) carbonyl carbene complexes indicate that this class of carbene is the most basic carbene ligand known to date. ${ }^{230}$

A review of $\mathrm{C}-\mathrm{C}$ bond formation in reactions between alkynes and group 9 metals to give cumulene complexes and conjugated alkenes has been published. ${ }^{231}$ Other cumulene complexes include the first structurally characterised transition metal complex with a $\mathrm{M}=\mathrm{C}=\mathrm{C}=\mathrm{C}=\mathrm{CR}_{2}(\mathrm{M}=\mathrm{Ir})$ moiety, ${ }^{232}$ and the preparation and use of iridium cumulenes. ${ }^{233}$ An IR and Raman spectroscopic study of rhodium(I) vinylidene and carbonyl complexes coupled with DFT calculations has also allowed evaluation of the $\mathrm{Rh}-\mathrm{C}$ bond strength free from mass effects. ${ }^{234}$ Iridabenzenes and their valence isomers including the transformation from iridabenzene $\mathbf{2 6}$ to $\eta^{5}$-cyclopentadienyl $27,{ }^{235}$ and $\mathrm{Tp}$ complexes that exhibit a metallocyclopentene to metallocyclopentadiene-alkene reaction have also been investigated. ${ }^{236}$

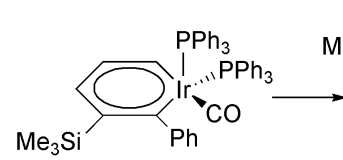

26

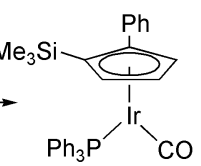

27

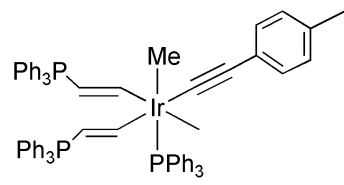

28

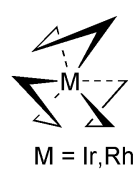

29

Articles describing, or of relevance to, catalytic reactions of group 9 metals that have not been mentioned above include the detection by in situ IR spectroscopy of the 'missing link' $\left[\mathrm{HRh}(\mathrm{CO})_{4}\right]$ for the first time, ${ }^{4}$ the use of parahydrogen for the detection 
of rhodium and iridium species present in very low concentration during hydroformylation of alkenes, ${ }^{237,238}$ the nature and roles of catalytic promoters in late metal carbonylation reactions, ${ }^{239}$ and a DFT study of cobalt-mediated alkene polymerisation which detects an inverse isotope effect due to a $\beta$-agostic interaction in the resting state of the catalyst $\left[\mathrm{Cp} * \mathrm{Co}(\mathrm{Et})\left(\mathrm{P}(\mathrm{OMe})_{3}\right)\right]^{+} .^{240}$ Important alkyl coupling reactions have also been investigated including cobalt-catalysed Heck-type reactions between alkyl halides and styrene ${ }^{241}$ and alkyl halides and allylic Grignard reagents. ${ }^{242}$ The direct observation and mechanism of aldehyde insertion into rhodium(I) aryl and alkoxide complexes has also been reported and intermediates characterised. ${ }^{243}$

Aesthetically pleasing compounds include the synthesis of the iridium complex $\mathbf{2 8}$ that contains four types of $\mathrm{Ir}-\mathrm{C} \sigma$-bonds ${ }^{244}$ and the structure and dynamics of the known complexes $\left[\mathrm{Rh}(\text { allyl })_{3}\right]$ and $\left[\operatorname{Ir}(\text { allyl })_{3}\right]$ that have been determined by DFT and corroborated by detailed PES, NMR and Raman studies. Both [Rh(allyl $\left.)_{3}\right]$ and $\left[\operatorname{Ir}(\text { allyl })_{3}\right]$ exhibit a psuedo-octahedral structure 29 , with no symmetry $\left(\mathrm{C}_{1}\right)$ in the ground state. ${ }^{245}$

\section{Nickel, palladium, platinum}

Relevant reviews of group 10 metal chemistry cover ligand-to-ligand charge transfer states and photochemical Pt-C bond homolysis, ${ }^{246}$ group 10 metal indenyl complexes ${ }^{247}$ copolymerisation of carbon monoxide and alkenes, ${ }^{248}$ and palladiumcatalysed coupling reactions of aryl chlorides. ${ }^{249}$

The fundamental understanding of $\mathrm{C}-\mathrm{H}$ bond activation using group 10 metal complexes and its application to organic synthesis received considerable attention in 2002. These include the ligand and electronic effects of $\mathrm{C}-\mathrm{H}$ bond activation in arenes by cationic platinum(II) diimime ${ }^{250}$ and bisphosphine complexes, ${ }^{251}$ the latter concomitant with $\mathrm{C}-\mathrm{C}$ coupling to give platinum bound bridging biaryls. The volume of activation of benzene $\mathrm{C}-\mathrm{H}$ activation in platinum(II) diimine complexes has also been measured. ${ }^{252}$ Alkyl ligand exchange with alkanes for platinum(II) cationic complexes has been studied ${ }^{253}$ and a novel platinum(II) olefin hydride $\mathbf{3 0}$ for alkane activation studies prepared. ${ }^{254}$ The complex $\left[\mathrm{PtMe}(\mathrm{H})_{2} \mathrm{Tp}\right]$ has also been shown to form a $\sigma-\mathrm{CH}_{4}$ complex that is kinetically resistant to methane liberation ${ }^{255}$ and the metal has been shown to be the kinetic site of protonation in diimine platinum(II) dimethyl complexes. ${ }^{256}$ The application of asymmetric activation to an $\mathrm{sp}^{3}$ hybridised $\mathrm{C}-\mathrm{H}$ bond

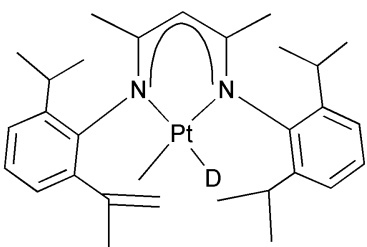

30

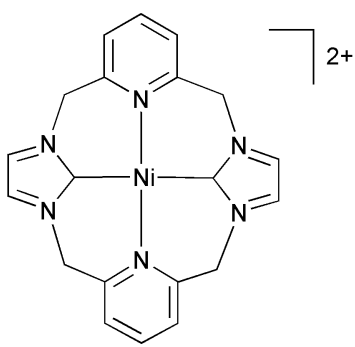

31

Annu. Rep. Prog. Chem., Sect. A, 2003, 99, 349-369 
using platinum(II) complexes for the total synthesis of (-)-rhazinilam has also been elegantly demonstrated. ${ }^{257}$ Theoretical work includes a DFT study on the mechanism of $\mathrm{C}-\mathrm{X}(\mathrm{X}=\mathrm{Sn}, \mathrm{Ge}, \mathrm{Si}, \mathrm{C}, \mathrm{H})$ activation in $\left[\mathrm{M}\left(\mathrm{PH}_{3}\right)_{2}\right](\mathrm{M}=\mathrm{Ni}, \mathrm{Pd}, \mathrm{Pt})$ investigating the orientation of the substrate with respect to the $\mathrm{MP}_{2}$ plane prior to oxidative addition. ${ }^{258}$ The conversion of methane to methanol using a palladium(II) chelating $\mathrm{N}$-heterocyclic carbene complex has been investigated, ${ }^{259}$ DFT studies on the stability and thermodynamics of $\mathrm{PtCl}_{2}$ derived catalysts for the activation of methane to methanol at low temperature in concentrated sulfuric acid ${ }^{260}$ and related theoretical work on the $\beta$-hydrogen elimination reactions of palladium and platinum alkoxide complexes have been published. ${ }^{261}$ Structural and mechanistic investigations of the reaction between $\left[\mathrm{PtMe}_{2}(\mathrm{tmeda})\right]$ and dioxygen to give the methoxy-hydroperoxy compound $\left[\mathrm{Pt}\left(\mathrm{CH}_{3}\right)_{2}\left(\mathrm{OCH}_{3}\right)(\mathrm{OOH})(\right.$ tmeda $\left.)\right]$ have also been performed. ${ }^{262}$ Selective palladium-catalysed oxidative coupling of analides with olefins via $\mathrm{C}-\mathrm{H}$ activation at room temperature, as shown in Scheme 4, is a good example of a Heck-type coupling reaction that avoids stoichiometric quantities of salt waste. ${ }^{263}$

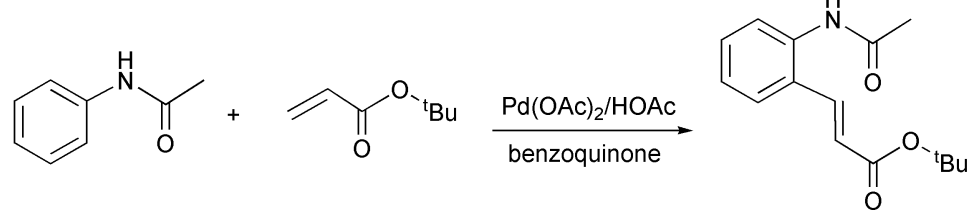

Scheme 4

Other reactions incorporating $\mathrm{C}-\mathrm{X}$ bond cleavage include routes to fluorinated organic derivatives by nickel-mediated $\mathrm{C}-\mathrm{F}$ activation of heteroaromatics, ${ }^{264}$ nickelmediated $\mathrm{C}-\mathrm{F}$ activation in the presence of a $\mathrm{C}-\mathrm{Cl}$ bond, ${ }^{265}$ temperature dependent $\mathrm{C}-\mathrm{H}$ or $\mathrm{C}-\mathrm{F}$ cleavage in platinum(II) arylamides, ${ }^{266} \mathrm{C}-\mathrm{C}$ bond cleavage of aromatic nitriles using nickel $(0)$ complexes, ${ }^{267} \mathrm{C}-\mathrm{N}$ cleavage and formation in nickel-aziridine chemistry, ${ }^{268}$ and thermal and photochemical $\mathrm{C}-\mathrm{Si}$ bond activation of $\mathrm{Me}_{3} \mathrm{SiCCPh}$ by platinum(0). ${ }^{269}$

$\mathrm{N}$-Heterocyclic carbene complexes of group 10 metals continue to be developed and applied to a number of catalytic processes including the meta-cyclophane nickel(II) complex 31 that adopts a saddle-shape, ${ }^{270}$ the first example of simple oxidative addition of an aryl chloride to a palladium(0) bis-N-heterocyclic carbene complex, ${ }^{271}$ cationic and neutral palladium(II) methyl complexes, ${ }^{272}$ palladium-catalysed Suzuki cross-coupling of aryl chlorides at room temperature, ${ }^{273}$ chiral palladium(II) $\mathrm{N}$-heterocyclic carbene-oxazoline complexes, ${ }^{274}$ tridentate pincer bis-carbene ligands ${ }^{275}$ and palladium(II) allyl complexes ${ }^{276}$ for a range of $\mathrm{C}-\mathrm{C}$ coupling reactions, palladium-catalysed telomerisation of 1,3-dienes and alcohols, ${ }^{277}$ and nickel(II)catalysed alkene dimerisation. ${ }^{278}$ Of relevance to some catalytic reactions is a combined theoretical and experimental study of a reductive elimination mechanism in a tridentate bis-carbene pyridene palladium(II) methyl complex. ${ }^{279}$

Polymerisation and copolymerisation using group 10 derived catalysts continues to be an active area of research, particularly the incorporation of polar monomers into polymer products. Detailed DFT studies have attempted to outline the challenges for the copolymerisation of alkenes and $\mathrm{N}$-containing polar monomers, including nitriles 
and amines, using nickel(II) and palladium(II) precatalysts. ${ }^{\mathbf{2 8 0 , 2 8 1}}$ Experimental investigations include a comparison between early and late metal (palladium) catalysed polymerisation of polar monomers that describes the importance of relative rates of insertion and substitution ${ }^{282}$ and the copolymerisation of ethene and alkylacrylates. ${ }^{283}$ In palladium-catalysed ethene/CO copolymerisation studies using a new class of $o$-alkoxy phosphine ligand, a non-perfectly alternating copolymer was obtained for the first time, ${ }^{284}$ a charge neutral zwitterionic palladium(II) complex $\mathbf{3 2}$ has been developed, ${ }^{285}$ and the effects of various $\mathrm{P}-\mathrm{N}$ donor ligands investigated. ${ }^{286}$ In related chemistry palladium hydrido-solvento complexes for the catalytic methoxycarbonylation of ethene to methyl propanoate have been studied by spectroscopic and structural methods, ${ }^{287-289}$ and platinum(II) and platinum(IV) acyl and formyl complexes characterised. ${ }^{290}$

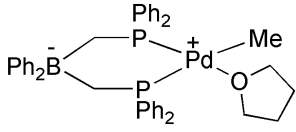

32

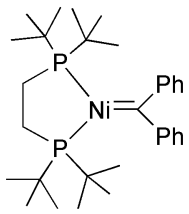

33

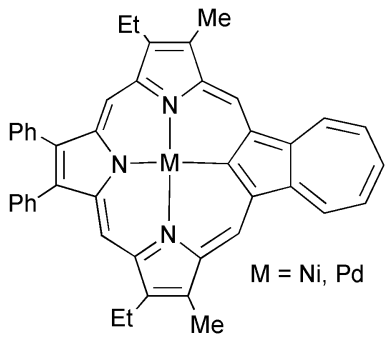

34

The synthesis and reactivity of a rare three-coordinate nickel( 0 ) carbene complex $\mathbf{3 3}$ has been investigated ${ }^{291}$ and the $\sigma$ - and $\pi$-bond activation at $\mathrm{Pd}=\mathrm{X}(\mathrm{Sn}, \mathrm{Si}, \mathrm{C})$ bonds in the complexes $\left[\mathrm{Pd}\left(\mathrm{H}_{2} \mathrm{PC}_{2} \mathrm{H}_{4} \mathrm{PH}_{2}\right)\left(\mathrm{XH}_{2}\right)\right]$ studied by DFT. ${ }^{292}$

Novel nickel(II) and palladium(II) azuliporphyrins $\mathbf{3 4}$ have also been isolated that retain cross-conjugated borderline aromatic structures as judged by UV-Vis and NMR spectroscopy, ${ }^{293}$ and a new family of square-planar nickel(II) carbonyl derivatives including cis- $\left[\mathrm{Ni}\left(\mathrm{C}_{6} \mathrm{~F}_{5}\right)_{2} \mathrm{Cl}(\mathrm{CO})\right]$ prepared. ${ }^{294}$

\section{References}

1 E. Despagnet, K. Miqueu, H. Gornitzka, P. W. Dyer, D. Bourissou and G. Bertrand, J. Am. Chem. Soc., 2002, 124, 11834

2 M. W. Bouwkamp, J. de Wolf, I. D. Morales, J. Gercama, A. Meetsma, S. I. Troyanov, B. Hessen and J. H. Teuben, J. Am. Chem. Soc., 2002, 124, 12956.

3 P. L. Holland, T. R. Cundari, L. L. Perez, N. A. Eckert and R. J. Lachicotte, J. Am. Chem. Soc., 2002, 124, 14416.

4 C. Z. Li, E. Widjaja, W. Chew and M. Garland, Angew. Chem., Int. Ed., 2002, 41, 3786.

5 W. A. Herrmann, Angew. Chem., Int. Ed., 2002, 41, 1291.

6 W. A. Herrmann, T. Weskamp and V. P. W. Böhm, Adv. Organomet. Chem., 2002, 48, 1.

7 C. Buron, L. Stelzig, O. Guerret, H. Gornitzka, V. Romanenko and G. Bertrand, J. Organomet. Chem., 2002, 664, 70

8 A. Wacker, C. G. Yan, G. Kaltenpoth, A. Ginsberg, A. M. Arif, R. D. Ernst, H. Pritzkow and W. Siebert, J. Organomet. Chem., 2002, 641, 195.

9 L. Bourget-Merle, M. F. Lappert and J. R. Severn, Chem. Rev., 2002, 102, 3031.

10 T. W. Hayton, P. Legzdins and W. B. Sharp, Chem. Rev., 2002, 102, 935.

11 J. Lee, L. Chen, A. H. West and G. B. Richter-Addo, Chem. Rev., 2002, 102, 1019.

12 R. R. Schrock, Chem. Rev., 2002, 102, 145.

13 Q. Xu, Coord. Chem. Rev., 2002, 231, 83. 
14 F. A. Cotton, Inorg. Chem., 2002, 41, 643.

15 M. J. Calhorda, C. C. Romao and L. F. Veiros, Chem. Eur. J., 2002, 8, 868.

16 P. J. Shapiro, Coord. Chem. Rev., 2002, 231, 67.

17 H. Mutoh and S. Masuda, Dalton Trans., 2002, 1875.

18 M. Ogasawara, T. Nagano and T. Hayashi, J. Am. Chem. Soc., 2002, 124, 9068.

19 S. Brydges, L. E. Harrington and M. J. McGlinchey, Coord. Chem. Rev., 2002, 233, 75.

20 M. Laskoski, W. Steffen, J. G. M. Morton, M. D. Smith and U. H. F. Bunz, Angew. Chem., Int. Ed., 2002, 41, 2378.

21 I. Emme, S. Redlich, T. Labahn, J. Magull and A. de Meijere, Angew. Chem., Int. Ed., 2002, 41, 786.

22 S. Y. Liu, I. D. Hills and G. C. Fu, Organometallics, 2002, 21, 4323.

23 T. J. Brunker, A. R. Cowley and D. O'Hare, Organometallics, 2002, 21, 3123.

24 J. A. Labinger and J. E. Bercaw, Nature, 2002, 417, 507.

25 E. Sicilia and N. Russo, J. Am. Chem. Soc., 2002, 124, 1471.

26 V. Ritleng, C. Sirlin and M. Pfeffer, Chem. Rev., 2002, 102, 1731

27 F. Kakiuchi and S. Murai, Accounts Chem. Res., 2002, 35, 826.

28 A. J. Hoskin and D. W. Stephan, Coord. Chem. Rev., 2002, 233, 107.

29 C. J. Curtis, A. Miedaner, W. W. Ellis and D. L. DuBois, J. Am. Chem. Soc., 2002, 124, 1918.

30 W. W. Ellis, A. Miedaner, C. J. Curtis, D. H. Gibson and D. L. DuBois, J. Am. Chem. Soc., 2002, 124, 1926.

31 K. Tamao, T. Hiyama and E.-i. Negishi, J. Organomet. Chem., 2002, 653, 1.

32 F. Alonso, I. P. Beletskaya and M. Yus, Chem. Rev., 2002, 102, 4009.

33 S. E. Denmark and R. F. Sweis, Acc. Chem. Res., 2002, 35, 835.

34 K. Fagnou and M. Lautens, Angew. Chem., Int. Ed., 2002, 41, 26.

35 J. Hassan, M. Sevignon, C. Gozzi, E. Schulz and M. Lemaire, Chem. Rev, 2002, 102, 1359.

36 C. J. Li, Acc. Chem. Res., 2002, 35, 533.

37 D. Sinou, Adv. Synth. Catal., 2002, 344, 221.

38 R. S. Paley, Chem. Rev., 2002, 102, 1493.

39 B. M. Trost, Acc. Chem. Res., 2002, 35, 695.

40 J. Dupont, R. F. de Souza and P. A. Z. Suarez, Chem. Rev., 2002, 102, 3667.

41 M. Larhed, C. Moberg and A. Hallberg, Acc. Chem. Res., 2002, 35, 717.

42 R. van Heerbeek, P. C. J. Kamer, P. van Leeuwen and J. N. H. Reek, Chem. Rev., 2002, 102, 3717.

43 M. H. Valkenberg and W. F. Holderich, Catal. Rev.-Sci. Eng., 2002, 44, 321.

44 G. W. Coates, Dalton Trans., 2002, 467.

45 S. Mecking, A. Held and F. M. Bauers, Angew. Chem., Int. Ed., 2002, 41, 545

46 D. M. Philipp, R. P. Muller, W. A. Goddard, J. Storer, M. McAdon and M. Mullins, J. Am. Chem. Soc., 2002, 124, 10198.

47 R. A. M. Robertson and D. J. Cole-Hamilton, Coord. Chem. Rev., 2002, 225, 67.

48 C. Aubert, O. Buisine and M. Malacria, Chem. Rev., 2002, 102, 813.

49 P. J. Low and M. I. Bruce, Adv. Organomet. Chem., 2002, 48, 72.

50 H. W. Fruhauf, Coord. Chem. Rev., 2002, 230, 79.

51 A. Vlcek, I. R. Farrell, D. J. Liard, P. Matousek, M. Towrie, A. W. Parker, D. C. Grills and M. W. George, Dalton Trans., 2002, 701 .

52 P. C. Ford and S. Massick, Coord. Chem. Rev., 2002, 226, 39.

53 I. G. Dance, P. A. W. Dean, K. J. Fisher and H. H. Harris, Inorg. Chem., 2002, 41, 3560.

54 C. E. Zachmanoglou, A. Docrat, B. M. Bridgewater, G. Parkin, C. G. Brandow, J. E. Bercaw, C. N. Jardine, M. Lyall, J. C. Green and J. B. Keister, J. Am. Chem. Soc., 2002, 124, 9525.

55 C. Alonso-Moreno, A. Antinolo, I. Lopez-Solera, A. Otero, S. Prashar, A. M. Rodriguez and E. Villasenor, J. Organomet. Chem., 2002, 656, 129.

56 A. Antinolo, I. Lopez-Solera, A. Otero, S. Prashar, A. M. Rodriguez and E. Villasenor, Organometallics, 2002, 21, 2460.

57 M. Horacek, P. Stepnicka, K. Fejfarova, R. Gyepes, I. Cisarova, J. Kubista and K. Mach, J. Organomet. Chem., 2002, 642, 148.

58 J. Imuta, N. Kashiwa and Y. Toda, J. Am. Chem. Soc., 2002, 124, 1176.

59 G. Altenhoff, S. Bredeau, G. Erker, G. Kehr, O. Kataeva and R. Frohlich, Organometallics, 2002, $21,4084$.

60 M. Kunz, G. Erker, S. Doring, S. Bredeau, G. Kehr and R. Frohlich, Organometallics, 2002, $21,1031$.

61 J. Z. Jin and E. Y. X. Chen, Organometallics, 2002, 21, 13.

62 J. Z. Jin, D. R. Wilson and E. Y. X. Chen, Chem. Commun., 2002, 708.

63 E. Y. Tshuva, S. Groysman, I. Goldberg, M. Kol and Z. Goldschmidt, Organometallics, 2002, $21,662$.

64 M. Mitani, R. Furuyama, J. Mohri, J. Saito, S. Ishii, H. Terao, N. Kashiwa and T. Fujita, J. Am. Chem. Soc., 2002, 124, 7888 .

65 M. Mitani, J. Mohri, Y. Yoshida, J. Saito, S. Ishii, K. Tsuru, S. Matsui, R. Furuyama, T. Nakano,

H. Tanaka, S. Kojoh, T. Matsugi, N. Kashiwa and T. Fujita, J. Am. Chem. Soc., 2002, 124, 3327.

66 P. D. Hustad and G. W. Coates, J. Am. Chem. Soc., 2002, 124, 11578.

67 P. D. Hustad, J. Tian and G. W. Coates, J. Am. Chem. Soc., 2002, 124, 3614.

68 P. D. Knight, A. J. Clarke, B. S. Kimberley, R. A. Jackson and P. Scott, Chem. Commun., 2002, 352.

69 W. P. Kretschmer, C. Dijkhuis, A. Meetsma, B. Hessen and J. H. Teuben, Chem. Commun., 2002, 608. 
70 S. Matsui, T. P. Spaniol, Y. Takagi, Y. Yoshida and J. Okuda, Dalton Trans., 2002, 4529.

71 Y. Yoshida, J. Saito, M. Mitani, Y. Takagi, S. Matsui, S. Ishii, T. Nakano, N. Kashiwa and T. Fujita, Chem. Commun., 2002, 1298.

72 A. N. Ryabov, V. V. Izmer, A. A. Borisenko, J. A. M. Canich, L. G. Kuz'mina, J. A. K. Howard and A. Z. Voskoboynikov, Dalton Trans., 2002, 2995.

73 R. J. Baker and P. G. Edwards, Dalton Trans., 2002, 2960.

74 R. J. Keaton, L. A. Koterwas, J. C. Fettinger and L. R. Sita, J. Am. Chem. Soc., 2002, 124, 5932.

75 R. J. Keaton and L. R. Sita, J. Am. Chem. Soc., 2002, 124, 9070.

76 M. Lin, G. J. Spivak and M. C. Baird, Organometallics, 2002, 21, 2350.

77 P. J. W. Deckers and B. Hessen, Organometallics, 2002, 21, 5564.

78 J. E. Kickham, F. Guerin and D. W. Stephan, J. Am. Chem. Soc., 2002, 124, 11486.

79 T. R. Cundari, T. R. Klinckman and P. T. Wolczanski, J. Am. Chem. Soc., 2002, 124, 1481.

80 A. D. Sadow and T. D. Tilley, J. Am. Chem. Soc., 2002, 124, 6814.

81 B. M. Kraft and W. D. Jones, J. Am. Chem. Soc., 2002, 124, 8681.

82 B. M. Kraft and W. D. Jones, J. Organomet. Chem., 2002, 658, 132.

83 B. M. Kraft, R. J. Lachicotte and W. D. Jones, Organometallics, 2002, 21, 727.

84 A. J. Ashe, H. Yang, X. D. Fang and J. W. Kampf, Organometallics, 2002, 21, 4578.

85 R. M. Chin, M. S. Jarosh, J. D. Russell and R. J. Lachicotte, Organometallics, 2002, $21,2027$.

86 P. J. Alonso, J. Fornies, M. A. Garcia-Monforte, A. Martin and B. Menjon, Chem. Commun., 2002, 728.

87 F. X. Buzin, F. Nief, L. Ricard and F. Mathey, Organometallics, 2002, 21, 259.

88 T. Agapie, P. L. Diaconescu, D. J. Mindiola and C. C. Cummins, Organometallics, 2002, 21, 1329.

89 V. Kulsomphob, A. M. Arif and R. D. Ernst, Organometallics, 2002, 21, 3182.

90 T. Takahashi, M. Ishikawa and S. Q. Huo, J. Am. Chem. Soc., 2002, 124, 388.

91 N. E. Schlorer, E. J. Cabrita and S. Berger, Angew. Chem., Int. Ed., 2002, 41, 107.

92 A. Antinolo, T. Exposito, I. del Hierro, D. Lucas, Y. Mugnier, I. Orive, A. Otero and S. Prashar, J. Organomet. Chem., 2002, 655, 63.

93 S. G. Feng, G. R. Roof and E. Y. X. Chen, Organometallics, 2002, 21, 832.

94 S. Bradley, K. D. Camm, S. J. Furtado, A. L. Gott, P. C. McGowan, T. J. Podesta and M. Thornton-Pett, Organometallics, 2002, 21, 3443.

95 R. Choukroun, C. Lorber and B. Donnadieu, Organometallics, 2002, 21, 1124.

96 K. S. Cook, W. E. Piers and R. McDonald, J. Am. Chem. Soc., 2002, 124, 5411.

97 K. S. Cook, W. E. Piers, P. G. Hayes and M. Parvez, Organometallics, 2002, 21, 2422.

98 W. W. Brennessel, J. E. Ellis, M. K. Pomije, V. J. Sussman, E. Urnezius and V. G. Young, J. Am. Chem. Soc., 2002, 124, 10258.

99 W. W. Brennessel, J. E. Ellis, S. N. Roush, B. R. Strandberg, O. E. Woisetschlager and V. G. Young, Chem. Commun., 2002, 2356.

100 C. Elschenbroich, F. Lu and K. Harms, Organometallics, 2002, 21, 5152.

101 F. Abu-Hasanayn, P. H. Y. Cheong and M. Oliff, Angew. Chem., Int. Ed., 2002, 41, 2120.

102 U. Burckhardt, G. L. Casty, J. Gavenonis and T. D. Tilley, Organometallics, 2002, 21, 3108

103 G. I. Nikonov, S. F. Vyboishchikov, L. G. Kuzmina and J. A. K. Howard, Chem. Commun., 2002, 568.

104 M. D. Fryzuk, C. M. Kozak, M. R. Bowdridge and B. O. Patrick, Organometallics, 2002, 21, 5047.

105 D. C. Bregel, S. M. Oldham and R. Eisenberg, J. Am. Chem. Soc., 2002, 124, 13827.

106 A. Galindo, M. Gomez, P. Gomez-Sal, A. Martin, D. del Rio and F. Sanchez, Organometallics, 2002, 21, 293.

107 Y. Matsuo, K. Mashima and K. Tani, Organometallics, 2002, 21, 138.

108 I. Shibata, T. Kano, N. Kanazawa, S. Fukuoka and A. Baba, Angew. Chem., Int. Ed., 2002, 41, 1389.

109 D. Caraiman, G. K. Koyanagi, A. Cunje, A. C. Hopkinson and D. K. Bohme, Organometallics, 2002, 21, 4293.

110 D. Seyferth, Organometallics, 2002, 21, 1520.

111 D. Seyferth, Organometallics, 2002, 21, 2800.

112 R. H. Mitchell, Z. Brkic, D. J. Berg and T. M. Barclay, J. Am. Chem. Soc., 2002, 124, 11983.

113 A. Berger, J. P. Djukic and C. Michon, Coord. Chem. Rev., 2002, 225, 215.

114 T. Hascall, M. H. Baik, B. A. Bridgewater, J. H. Shin, D. G. Churchill, R. A. Friesner and G. Parkin, Chem. Commun., 2002, 2644.

115 C. J. Adams, I. M. Bartlett, N. G. Connelly, D. J. Harding, O. D. Hayward, A. J. Martin, A. G. Orpen, M. J. Quayle and P. H. Rieger, Dalton Trans., 2002, 4281.

116 P. J. Alonso, J. Fornies, M. A. Garcia-Monforte, A. Martin, B. Menjon and C. Rillo, Chem. Eur. J., 2002, 8, 4056.

117 E. D. Brady, J. S. Overby, M. B. Meredith, A. B. Mussman, M. A. Cohn, T. P. Hanusa, G. T. Yee and M. Pink, J. Am. Chem. Soc., 2002, 124, 9556.

118 T. J. Brunker, J. C. Green and D. O’Hare, Inorg. Chem., 2002, 41, 1701.

119 M. Kaupp, T. Kopf, A. Murso, D. Stalke, C. Strohmann, J. R. Hanks, F. G. N. Cloke and P. B. Hitchcock, Organometallics, 2002, 21, 5021.

120 C. Menoret, A. Spasojevic-de Bire, N. Q. Dao, A. Cousson, J. M. Kiat, J. D. Manna and M. D. Hopkins, Dalton Trans., 2002, 3731 
121 J. C. Green, J. N. Harvey and R. Poli, Dalton Trans., 2002, 1861.

122 Y. Fan and M. B. Hall, Dalton Trans., 2002, 713.

123 C. S. Adams, P. Legzdins and E. Tran, Organometallics, 2002, 21, 1474.

124 S. H. K. Ng, C. S. Adams and P. Legzdins, J. Am. Chem. Soc., 2002, 124, 9380.

125 K. Wada, C. B. Pamplin and P. Legzdins, J. Am. Chem. Soc., 2002, 124, 9680.

126 J. H. Shin, D. G. Churchill and G. Parkin, J. Organomet. Chem., 2002, $642,9$.

127 S. K. Tipparaju, S. K. Mandal, S. Sur, V. G. Puranik and A. Sarkar, Chem. Commun., 2002, 1924

128 L. Y. Goh, Z. Q. Weng, A. T. S. Hor and W. K. Leong, Organometallics, 2002, 21, 4408.

129 G. Zhu, J. M. Tanski, D. G. Churchill, K. E. Janak and G. Parkin, J. Am. Chem. Soc., 2002, 124, 13658.

130 K. E. Janak, J. M. Tanski, D. G. Churchill and G. Parkin, J. Am. Chem. Soc., 2002, 124, 4182.

131 L. A. Berben and J. R. Long, J. Am. Chem. Soc., 2002, 124, 11588.

132 E. Katayev, Y. H. Li and A. L. Odom, Chem. Commun., 2002, 838.

133 J. Perez, L. Riera, V. Riera, S. Garcia-Granda, E. Garcia-Rodriguez and D. Miguel, Organometallics, 2002, 21, 1622.

134 J. Perez, L. Riera, V. Riera, S. Garcia-Granda, E. Garcia-Rodriguez and D. Miguel, Chem. Commun., $2002,384$.

135 A. D. Burrows, N. Carr, M. Green, J. M. Lynam, M. F. Mahon, M. Murray, B. Kiran, M. T. Nguyen and C. Jones, Organometallics, 2002, 21, 3076.

136 X. Y. Li, M. Schopf, J. Stephan, M. Harms and J. Sundermeyer, Organometallics, 2002, $21,2356$.

137 D. M. J. Foo, P. J. Sinnema, B. Twamley and P. J. Shapiro, Organometallics, 2002, 21, 1005.

138 P. J. Sinnema, P. J. Shapiro, D. M. J. Foo and B. Twamley, J. Am. Chem. Soc., 2002, 124, 10996.

139 O. M. Heigl, E. Herdtweck, S. Grasser, F. H. Kohler, W. Strauss and H. Zeh, Organometallics, 2002, 21, 3572 .

140 M. H. Voges and R. M. Bullock, Dalton Trans., 2002, 759.

141 M. Tamm, T. Bannenberg, B. Dressel, R. Frohlich and C. Holst, Inorg. Chem., 2002, 41, 47.

142 Y. Arano, Ann. Nucl. Med., 2002, 16, 79.

143 B. Johannsen and H. J. Pietzsch, Eur. J. Nucl. Med. Mol. Imaging, 2002, 29, 263.

144 R. Schibli and P. A. Schubiger, Eur. J. Nucl. Med. Mol. Imaging, 2002, 29, 1529.

145 A. J. Downs, M. R. Geisberger, J. C. Green, T. M. Greene, A. Haaland, W. A. Herrmann, L. J. Morris, S. Parsons, S. B. Wolfgang and H. V. Volden, Dalton Trans., 2002, 3342.

146 A. J. Downs, G. Dierker, J. C. Green, T. M. Greene, G. S. McGrady, L. J. Morris, S. D. Wolfgang and P. Sirsch, Dalton Trans., 2002, 3349.

147 L. J. Morris, A. J. Downs, J. C. Green, T. M. Greene, S. J. Teat and S. Parsons, Dalton Trans., $2002,3142$.

148 X. P. Shan, A. Ellern and J. H. Espenson, Inorg. Chem., 2002, 41, 7136.

149 X. P. Shan, A. Ellern and J. H. Espenson, Angew. Chem., Int. Ed., 2002, 41, 3807.

150 W. D. Wang, A. Ellern, I. A. Guzei and J. H. Espenson, Organometallics, 2002, 21, 5576.

151 R. J. Baker, P. G. Edwards, J. Garcia-Mora, F. Ingold and K. M. A. Malik, Dalton Trans., $2002,3985$.

152 A. M. Gillespie, G. R. Morello and D. P. White, Organometallics, 2002, 21, 3913.

153 F. De Angelis, A. Sgamellotti and N. Re, Organometallics, 2002, 21, 2715.

154 G. J. Reiss and S. Konietzny, Dalton Trans., 2002, 862.

155 D. L. Lichtenberger, N. E. Gruhn, A. Rai-Chaudhuri, S. K. Renshaw, J. A. Gladysz, H. J. Jiao, J. Seyler and A. Igau, Organometallics, 2002, 21, 5494.

156 E. Bencze, J. Mink, C. Nemeth, W. A. Herrmann, B. V. Lokshin and F. E. Kuhn, J. Organomet. Chem., 2002, 642, 246.

157 S. M. Massick, V. Mertens, J. Marhenke and P. C. Ford, Inorg. Chem., 2002, 41, 3553.

158 R. Shiozawa, H. Tobita and H. Ogino, J. Organomet. Chem., 2002, 650, 91.

159 N. Mantovani, L. Marvelli, R. Rossi, V. Bertolasi, C. Bianchini, I. de los Rios and M. Peruzzini, Organometallics, 2002, 21, 2382.

160 C. P. Casey, T. M. Boller, S. Kraft and I. A. Guzei, J. Am. Chem. Soc., 2002, 124, 13215.

161 V. Riollet, C. Coperet, J. M. Basset, L. Rousset, D. Bouchu, L. Grosvalet and M. Perrin, Angew. Chem., Int. Ed., 2002, 41, 3025 .

162 D. S. Bohle, W. C. Chen and C. H. Hung, Inorg. Chem., 2002, 41, 3334.

163 J. R. Bryant, J. E. Taves and J. M. Mayer, Inorg. Chem., 2002, 41, 2769.

164 R. S. Bogadi, D. C. Levendis and N. J. Coville, J. Am. Chem. Soc., 2002, 124, 1104.

165 C. M. Che and J. S. Huang, Coord. Chem. Rev., 2002, 231, 151.

166 C. A. Turner, W. Ding, I. J. Amster and C. Kutal, Coord. Chem. Rev., 2002, 229, 9.

167 J. J. Van Veldhuizen, S. B. Garber, J. S. Kingsbury and A. H. Hoveyda, J. Am. Chem. Soc., 2002, $124,4954$.

168 H. Wakamatsu and S. Blechert, Angew. Chem., Int. Ed., 2002, 41, 2403.

169 S. E. Vyboishchikov, M. Buhl and W. Thiel, Chem. Eur. J., 2002, 8, 3962.

170 R. G. Carlson, M. A. Gile, J. A. Heppert, M. H. Mason, D. R. Powell, D. Vander Velde and J. M. Vilain, J. Am. Chem. Soc., 2002, 124, 1580.

171 G. J. P. Britovsek, V. C. Gibson, S. K. Spitzmesser, K. P. Tellmann, A. J. P. White and D. J. Williams, Dalton Trans., 2002, 1159.

172 H. W. Boone, P. S. Athey, M. J. Mullins, D. Philipp, R. Muller and W. A. Goddard, J. Am. Chem. Soc., 2002, 124, 8790 . 
173 R. F. R. Jazzar, S. A. Macgregor, M. F. Mahon, S. P. Richards and M. K. Whittlesey, J. Am. Chem. Soc., 2002, 124, 4944.

174 D. G. Gusev and A. J. Lough, Organometallics, 2002, 21, 2601.

175 V. F. Kuznetsov, A. J. Lough and D. G. Gusev, Chem. Commun., 2002, 2432.

176 E. Ruba, K. Mereiter, R. Schmid, K. Kirchner, E. Bustelo, M. C. Puerta and P. Valerga, Organometallics, 2002, 21, 2912.

177 G. Ferrando-Miguel, H. Gerard, O. Eisenstein and K. G. Caulton, Inorg. Chem., 2002, 41, 6440.

178 D. Schott, C. J. Sleigh, J. P. Lowe, S. B. Duckett, R. J. Mawby and M. G. Partridge, Inorg. Chem., 2002, 41, 2960.

179 J. Vela, J. M. Smith, R. J. Lachicotte and P. L. Holland, Chem. Commun., 2002, 2886.

180 M. Baya and M. A. Esteruelas, Organometallics, 2002, 21, 2332.

181 M. Baya, M. A. Esteruelas and E. Onate, Organometallics, 2002, 21, 5681.

182 J. J. Carbo, P. Crochet, M. A. Esteruelas, Y. Jean, A. Lledos, A. M. Lopez and E. Onate, Organometallics, 2002, 21, 305.

183 D. R. Muhandiram, G. Y. Kiel, G. H. M. Aarts, I. M. Saez, J. G. A. Reuvers, D. M. Heinekey, W. A. G. Graham, J. Takats and R. E. D. McClung, Organometallics, 2002, 21, 2687.

184 I. Atheaux, F. Delpech, B. Donnadieu, S. Sabo-Etienne, B. Chaudret, K. Hussein, J. C. Barthelat, T. Braun, S. B. Duckett and R. N. Perutz, Organometallics, 2002, 21, 5347.

185 S. T. N. Freeman, F. R. Lemke and L. Brammer, Organometallics, 2002, 21, 2030.

186 A. Furstner and A. Leitner, Angew. Chem., Int. Ed., 2002, 41, 609.

187 E. J. Farrington, J. M. Brown, C. F. J. Barnard and E. Rowsell, Angew. Chem., Int. Ed., 2002, 41, 169.

188 A. A. Danopoulos, S. Winston and W. B. Motherwell, Chem. Commun., 2002, 1376.

189 L. Busetto, M. C. Cassani, R. Mazzoni, V. G. Albano, P. Sabatino, P. Frediani and E. Rivalta, Organometallics, 2002, 21, 4993.

190 M. Lotz, K. Polborn and P. Knochel, Angew. Chem., Int. Ed., 2002, 41, 4708.

191 L. D. Field, T. W. Hambley, P. A. Humphrey, A. F. Masters and P. Turner, Inorg. Chem., 2002, $41,4618$.

192 F. Moulines, M. Kalam-Alami, V. Martinez and D. Astruc, J. Organomet. Chem., 2002, $643,125$.

193 R. Baldwin, M. A. Bennett, D. C. R. Hockless, P. Pertici, A. Verrazzani, G. U. Barretta, F. Marchetti and P. Salvadori, Dalton Trans., 2002, 4488.

194 K. Ferre, L. Toupet and V. Guerchais, Organometallics, 2002, 21, 2578.

195 A. C. Filippou and T. Rosenauer, Angew. Chem., Int. Ed., 2002, 41, 2393.

196 D. G. Gusev, T. Maxwell, F. N. Dolgushin, M. Lyssenko and A. J. Lough, Organometallics, 2002, $21,1095$.

197 S. Conejero, J. Diez, M. P. Gamasa, J. Gimeno and S. Garcia-Granda, Angew. Chem., Int. Ed., 2002, 41, 3439.

198 T. Y. Cheng and R. M. Bullock, Organometallics, 2002, 21, 2325.

199 B. M. Trost and C. M. Older, Organometallics, 2002, 21, 2544.

200 B. T. Carter, M. P. Castellani, A. L. Rheingold, S. Hwang, S. E. Longacre and M. G. Richmond, Organometallics, 2002, 21, 373.

201 T. Ishiyama, J. Takagi, J. F. Hartwig and N. Miyaura, Angew. Chem., Int. Ed., 2002, 41, 3056.

202 T. Ishiyama, J. Takagi, K. Ishida, N. Miyaura, N. R. Anastasi and J. F. Hartwig, J. Am. Chem. Soc., 2002, 124, 390.

203 X. H. Wan, X. J. Wang, Y. Luo, S. Takami, M. Kubo and A. Miyamoto, Organometallics, 2002, $21,3703$.

204 S. R. Klei, J. T. Golden, T. D. Tilley and R. G. Bergman, J. Am. Chem. Soc., 2002, 124, 2092.

205 S. R. Klei, T. D. Tilley and R. G. Bergman, Organometallics, 2002, 21, 4905.

206 K. Krogh-Jespersen, M. Czerw, K. M. Zhu, B. Singh, M. Kanzelberger, N. Darji, P. D. Achord, K. B. Renkema and A. S. Goldman, J. Am. Chem. Soc., 2002, 124, 10797.

207 K. Krogh-Jespersen, M. Czerw, N. Summa, K. B. Renkema, P. D. Achord and A. S. Goldman, J. Am. Chem. Soc., 2002, 124, 11404.

208 K. L. Tan, R. G. Bergman and J. A. Ellman, J. Am. Chem. Soc., 2002, 124, 13964.

209 C. H. Jun, C. W. Moon and D. Y. Lee, Chem. Eur. J., 2002, 8, 2423.

210 H. Wadepohl, A. Metz and H. Pritzkowl, Chem. Eur. J., 2002, 8, 1591.

211 S. Gründemann, A. Kovacevic, M. Albrecht, J. W. Faller and R. H. Crabtree, J. Am. Chem. Soc., 2002, 124, 10473.

212 D. M. Tellers, C. M. Yung, B. A. Arndtsen, D. R. Adamson and R. G. Bergman, J. Am. Chem. Soc., 2002, 124, 1400.

213 F. L. Taw, P. S. White, R. G. Bergman and M. Brookhart, J. Am. Chem. Soc., 2002, 124, 4192.

214 S. R. Klei, T. D. Tilley and R. G. Bergman, Organometallics, 2002, 21, 4648.

215 A. A. Danopoulos, S. Winston and M. B. Hursthouse, Dalton Trans., 2002, 3090.

216 K. L. Tan, R. G. Bergman and J. A. Ellman, J. Am. Chem. Soc., 2002, 124, 3202.

217 E. Clot, O. Eisenstein, T. Dube, J. W. Faller and R. H. Crabtree, Organometallics, 2002, $21,575$.

218 P. J. Albietz, J. F. Houlis and R. Eisenberg, Inorg. Chem., 2002, 41, 2001.

219 T. Braun, D. Noveski, B. Neumann and H. G. Stammler, Angew. Chem., Int. Ed., 2002, 41, 2745.

220 R. P. Hughes, D. H. Zhang, L. N. Zakharov and A. L. Rheingold, Organometallics, 2002, $21,4902$.

221 R. P. Hughes, R. B. Laritchev, A. Williamson, C. D. Incarvito, L. N. Zakharov and A. L. Rheingold, Organometallics, 2002, 21, 4873. 
222 R. M. Bellabarba, M. Nieuwenhuyzen and G. C. Saunders, Organometallics, 2002, 21, 5726.

223 F. M. Dixon, J. R. Farrell, P. E. Doan, A. Williamson, D. A. Weinberger, C. A. Mirkin, C. Stern, C. D. Incarvito, L. M. Liable-Sands, L. N. Zakharov and A. L. Rheingold, Organometallics, 2002, 21, 3091.

224 S. Deblon, L. Liesum, J. Harmer, H. Schonberg, A. Schweiger and H. Grutzmacher, Chem. Eur. J., 2002, 8, 601.

225 W. W. Brennessel, V. G. Young and J. E. Ellis, Angew. Chem., Int. Ed., 2002, 41, 1211.

226 M. Albrecht, R. H. Crabtree, J. Mata and E. Peris, Chem. Commun., 2002, 32.

227 M. Albrecht, J. R. Miecznikowski, A. Samuel, J. W. Faller and R. H. Crabtree, Organometallics, 2002, 21, 3596.

228 L. D. Vazquez-Serrano, B. T. Owens and J. M. Buriak, Chem. Commun., 2002, 2518.

229 R. W. Simms, M. J. Drewitt and M. C. Baird, Organometallics, 2002, 21, 2958.

230 K. Denk, P. Sirsch and W. A. Herrmann, J. Organomet. Chem., 2002, 649, 219.

231 C. S. Chin, G. Won, D. S. Chong, M. Kim and H. Lee, Acc. Chem. Res., 2002, 35, 218.

232 K. Ilg and H. Werner, Chem. Eur. J., 2002, 8, 2812.

233 H. Werner, K. Ilg, R. Lass and J. Wolf, J. Organomet. Chem., 2002, 661, 137.

234 D. Moigno, B. Callejas-Gaspar, J. Gil-Rubio, H. Werner and W. Kiefer, J. Organomet. Chem., 2002, 661, 181.

235 H. P. Wu, S. Lanza, T. J. R. Weakley and M. M. Haley, Organometallics, 2002, 21, 2824.

236 J. M. O'Connor, A. Closson and P. Gantzel, J. Am. Chem. Soc., 2002, 124, 2434.

237 C. Godard, P. Callaghan, J. L. Cunningham, S. B. Duckett, J. A. B. Lohman and R. N. Perutz, Chem. Commun., 2002, 2836.

238 S. K. Hasnip, S. A. Colebrooke, C. J. Sleigh, S. B. Duckett, D. R. Taylor, G. K. Barlow and M. J. Taylor, Dalton Trans., 2002, 743.

239 R. Whyman, A. P. Wright, J. A. Iggo and B. T. Heaton, Dalton Trans., 2002, 771.

240 A. Zeller and T. Strassner, Organometallics, 2002, 21, 4950.

241 Y. Ikeda, T. Nakamura, H. Yorimitsu and K. Oshima, J. Am. Chem. Soc., 2002, 124, 6514.

242 T. Tsuji, H. Yorimitsu and K. Oshima, Angew. Chem., Int. Ed., 2002, 41, 4137.

243 C. Krug and J. F. Hartwig, J. Am. Chem. Soc., 2002, 124, 1674.

244 C. S. Chin, M. Kim and H. Lee, Organometallics, 2002, 21, 1679.

245 K. D. John, R. Michalczyk, G. Hernandez, J. C. Green, R. L. Martin, R. T. Baker and A. P. Sattelberger, Organometallics, 2002, 21, 5757.

246 J. van Slageren, A. Klein and S. Zalis, Coord. Chem. Rev., 2002, 230, 193.

247 D. Zargarian, Coord. Chem. Rev., 2002, 233, 157.

248 C. Bianchini and A. Meli, Coord. Chem. Rev., 2002, 225, 35.

249 A. F. Littke and G. C. Fu, Angew. Chem., Int. Ed., 2002, 41, 4176.

250 H. A. Zhong, J. A. Labinger and J. E. Bercaw, J. Am. Chem. Soc., 2002, 124, 1378.

251 W. V. Konze, B. L. Scott and G. J. Kubas, J. Am. Chem. Soc., 2002, 124, 12550.

252 J. Procelewska, A. Zahl, R. van Eldik, H. A. Zhong, J. A. Labinger and J. E. Bercaw, Inorg. Chem., 2002, 41, 2808.

253 A. N. Vedernikov and K. G. Caulton, Angew. Chem., Int. Ed., 2002, 41, 4102.

254 U. Fekl and K. I. Goldberg, J. Am. Chem. Soc., 2002, 124, 6804.

255 H. C. Lo, A. Haskel, M. Kapon and E. Keinan, J. Am. Chem. Soc., 2002, 124, 3226.

256 B. J. Wik, M. Lersch and M. Tilset, J. Am. Chem. Soc., 2002, 124, 12116.

257 J. A. Johnson, L. Ning and D. Sames, J. Am. Chem. Soc., 2002, 124, 6900.

258 T. Matsubara and K. Hirao, Organometallics, 2002, 21, 4482.

259 M. Muehlhofer, T. Strassner and W. A. Herrmann, Angew. Chem., Int. Ed., 2002, 41, 1745.

260 J. Kua, X. Xu, R. A. Periana and W. A. Goddard, Organometallics, 2002, 21, 511.

261 S. M. Ng, C. Zhao and Z. Y. Lin, J. Organomet. Chem., 2002, 662, 120.

262 V. V. Rostovtsev, L. M. Henling, J. A. Labinger and J. E. Bercaw, Inorg. Chem., 2002, 41, 3608.

263 M. D. K. Boele, G. P. F. van Strijdonck, A. H. M. de Vries, P. C. J. Kamer, J. G. de Vries and P. van Leeuwen, J. Am. Chem. Soc., 2002, 124, 1586.

264 T. Braun and R. N. Perutz, Chem. Commun., 2002, 2749.

265 M. I. Sladek, T. Braun, B. Neumann and H. G. Stammler, Dalton Trans., 2002, 297.

266 A. C. Albeniz, V. Calle, P. Espinet and S. Gomez, Chem. Commun., 2002, 610.

267 J. J. Garcia, N. M. Brunkan and W. D. Jones, J. Am. Chem. Soc., 2002, 124, 9547.

268 B. L. Lin, C. R. Clough and G. L. Hillhouse, J. Am. Chem. Soc., 2002, 124, 2890.

269 C. Muller, R. J. Lachicotte and W. D. Jones, Organometallics, 2002, 21, 1190.

270 M. V. Baker, B. W. Skelton, A. H. White and C. C. Williams, Organometallics, 2002, 21, 2674.

271 S. Caddick, F. Geoffrey, N. Cloke, P. B. Hitchcock, J. Leonard, A. K. D. Lewis, D. McKerrecher and L. R. Titcomb, Organometallics, 2002, 21, 4318.

272 R. E. Douthwaite, M. L. H. Green, P. J. Silcock and P. T. Gomes, Dalton Trans., 2002, 1386.

273 C. W. K. Gstottmayr, V. P. W. Bohm, E. Herdtweck, M. Grosche and W. A. Herrmann, Angew. Chem. Int. Ed., 2002, 41, 1363 .

274 F. Glorius, G. Altenhoff, R. Goddard and C. Lehmann, Chem. Commun., 2002, 2704. 
275 J. A. Loch, M. Albrecht, E. Peris, J. Mata, J. W. Faller and R. H. Crabtree, Organometallics, 2002, 21, 700.

276 M. S. Viciu, R. F. Germaneau, O. Navarro-Fernandez, E. D. Stevens and S. P. Nolan, Organometallics, $2002,21,5470$.

277 R. Jackstell, M. G. Andreu, A. Frisch, K. Selvakumar, A. Zapf, H. Klein, A. Spannenberg, D. Rottger, O. Briel, R. Karch and M. Beller, Angew. Chem., Int. Ed., 2002, 41, 986.

278 D. S. McGuinness, W. Mueller, P. Wasserscheid, K. J. Cavell, B. W. Skelton, A. H. White and U. Englert, Organometallics, 2002, 21, 175.

279 D. J. Nielsen, A. M. Magill, B. F. Yates, K. J. Cavell, B. W. Skelton and A. H. White, Chem. Commun., 2002, 2500.

280 D. V. Deubel and T. Ziegler, Organometallics, 2002, 21, 4432.

281 D. V. Deubel and T. Ziegler, Organometallics, 2002, 21, 1603.

282 M. S. Kang, A. Sen, L. Zakharov and A. L. Rheingold, J. Am. Chem. Soc., 2002, 124, 12080.

283 E. Drent, R. van Dijk, R. van Ginkel, B. van Oort and R. I. Pugh, Chem. Commun., 2002, 744.

284 E. Drent, R. van Dijk, R. van Ginkel, B. van Oort and R. I. Pugh, Chem. Commun., 2002, 964.

285 C. C. Lu and J. C. Peters, J. Am. Chem. Soc., 2002, 124, 5272.

286 K. R. Reddy, W. W. Tsai, K. Surekha, G. H. Lee, S. M. Peng, J. T. Chen and S. T. Liu, Dalton Trans., 2002, 1776.

287 W. Clegg, G. R. Eastham, M. R. J. Elsegood, B. T. Heaton, J. A. Iggo, R. P. Tooze, R. Whyman and S. Zacchini, Dalton Trans., 2002, 3300.

288 W. Clegg, G. R. Eastham, M. R. J. Elsegood, B. T. Heaton, J. A. Iggo, R. P. Tooze, R. Whyman and S. Zacchini, Organometallics, 2002, 21, 1832.

289 G. R. Eastham, R. P. Tooze, M. Kilner, D. F. Foster and D. J. Cole-Hamilton, Dalton Trans., $2002,1613$.

290 S. Reinartz, M. Brookhart and J. L. Templeton, Organometallics, 2002, 21, 247.

291 D. J. Mindiola and G. L. Hillhouse, J. Am. Chem. Soc., 2002, 124, 9976.

292 T. Matsubara and K. Hirao, J. Am. Chem. Soc., 2002, 124, 679.

293 S. R. Graham, G. M. Ferrence and T. D. Lash, Chem. Commun., 2002, 894.

294 J. Fornies, A. Martin, L. F. Martin, B. Menjon, H. A. Kalamarides, L. F. Rhodes, C. S. Day and V. W. Day, Chem. Eur. J., 2002, 8, 4925. 
